NBER WORKING PAPER SERIES

\title{
WHEN DOES FUNDING RESEARCH \\ BY SMALLER FIRMS BEAR FRUIT?: \\ EVIDENCE FROM THE SBIR PROGRAM
}

\author{
Joshua S. Gans \\ Scott Stern
}

Working Paper 7877

http://www.nber.org/papers/w7877

\author{
NATIONAL BUREAU OF ECONOMIC RESEARCH \\ 1050 Massachusetts Avenue \\ Cambridge, MA 02138 \\ September 2000
}

The cooperation and assistance of the firms that contributed data used in this study is greatly appreciated. Josh Lerner, Scott Wallsten, Scott Shane, seminar participants at MIT, UCLA, Wharton, FTC and NBER, and especially Iain Cockburn, provided thoughtful suggestions and advice. David Hsu provided outstanding research assistance. We also gratefully acknowledge funding for this research by the MIT Center for Innovation in Product Development under NSF Cooperative Agreement \# EEC-9529140 and a Large Grant from the Australian Research Council. Any remaining errors or omissions are our responsibility. The views expressed herein are those of the authors and not necessarily those of the National Bureau of Economic Research.

(C) 2000 by Joshua S. Gans and Scott Stern. All rights reserved. Short sections of text, not to exceed two paragraphs, may be quoted without explicit permission provided that full credit, including $\mathbb{C}$ notice, is given to the source. 
When Does Funding Research by Smaller Firms Bear Fruit?: Evidence from the SBIR Program Joshua S. Gans and Scott Stern

NBER Working Paper No. 7877

September 2000

JEL No. G24, O31, O38

\begin{abstract}
$\underline{\text { ABSTRACT }}$
This paper evaluates whether the relative concentration of funding for small, research-oriented firms in a small number of high-tech industries is related to the differences across industries in the level of appropriability or capital constraints facing small firms. To do so, we exploit a novel test based on the relationship between industry-level private venture financing and the performance of governmentsubsidized R\&D projects in those sectors. If the government funds projects on the margin (as it should under an optimal subsidy regime) and industries only differ in terms of the level of appropriability, then private funding and subsidized project performance are positively correlated. Conversely, if industries only differ in terms of the level of capital constraints, this correlation is negative. Our principal empirical result is that project-level performance is highest for those technologies that are in industrial segments that attract high rates of venture capital investment. This result suggests that industrial sectors differ in the degree of appropriability for research-oriented small businesses and that variation in the appropriability regime helps explain the concentrated nature of venture capital activity in the economy.

Joshua S. Gans

Melbourne Business School

University of Melbourne

200 Leicester Street

Carlton Victoria, 3053

AUSTRALIA

j.gans@mbs.unimelb.edu.au

Scott Stern

Sloan School of Management

E52-554

MIT

50 Memorial Drive

Cambridge, MA 02139

and NBER

sstern@mit.edu
\end{abstract}




\section{Introduction}

At least since Nelson (1959) and Arrow (1962), economists have been aware that competitive markets may fail to provide the socially optimal level of $R \& D$ investment. Technological innovation is beset by uncertainty, imperfect monitoring and imperfect property rights that lead many to conclude that R\&D investment by private firms is too low (Griliches, 1998; Romer, 1990). In this context, special attention is paid to the role of small, entrepreneurial firms since such firms may be particularly susceptible to the capital and product market imperfections identified by Arrow and Nelson. Specifically, technology-based entrepreneurs may be unable to raise R\&D investment capital (Kamien and Schwartz, 1982; Holmstrom, 1989) and be poorly positioned to extract the social value created by their innovations (Teece, 1987; Anton and Yao, 1994).

From an empirical perspective, perhaps the most puzzling fact about innovation by small technology-based firms is how concentrated it is among a small number of economic sectors. Even after limiting attention to sectors which experience high overall rates of R\&D investment and innovation, only a small subset of these sectors are associated with high rates of R\&D investment innovation by small, entrepreneurial firms (National Science Foundation, 1999). For example, during the rapid increase in the level of venture capital financing during the 1990s, VC expenditures have been targeted at a relatively narrow set of sectors, such as software development, telecommunications, and biotechnology (Kortum and Lerner, 1998). These patterns raise a critical question: what are the drivers of inter-industry variation in small firm $\mathrm{R} \& \mathrm{D}$ financing? 
We address this question by considering three (not mutually exclusive) forces: technological opportunity, appropriability and capital constraints. To the extent that economic sectors vary according to these factors, $\mathrm{R} \& \mathrm{D}$ expenditures and realized rates of technological innovation will vary accordingly. For example, at a given point in time, some sectors may experience higher levels of technological opportunity (i.e., the ability to generate an innovation of a given social value for a given level of expenditure); it should not be surprising that these sectors are associated with the highest rates of $\mathrm{R} \& \mathrm{D}$ investment and realized innovation. Indeed, most prior analyses of the skewed distribution of $R \& D$ expenditures have focused on variation in the level of technological opportunity as the "culprit" for uneven financing and rates of technological change among economic sectors (Schmookler, 1966; Rosenberg, 1974; Adams, 1990). ${ }^{1}$

However, particularly when considering the distribution of innovative activity by smaller, more entrepreneurial, firms, concentration may also result from differences in the salience of either product market imperfections (i.e., appropriability) or capital market imperfections (i.e., capital constraints). Appropriability is the degree to which technological innovation results in spillovers to consumers or more established firms, thus limiting the extent to which an innovator extracts the marginal social product associated with their innovation. Small firms face particular appropriability problems, either because they are less likely to possess "complementary assets," such as a brand-name reputation, a distribution system, or installed base (Teece, 1987), or because of their relative inability to obtain complete intellectual property for their innovations (Anton and Yao, 1994; Gans and Stern, 2000). To the extent that sectors differ substantially in terms of the importance of complementary assets or the strength of intellectual property, it is

\footnotetext{
${ }^{1}$ Most quantitative work in this area attempts to analyze whether publicly financed basic research provides a spur to private R\&D expenditures by increasing the level of technological opportunity in specific areas (Adams, 1990;
} 
likely that sectors with low levels of appropriability will be associated with the lowest levels of investment and innovation by small research-oriented firms. ${ }^{2}$

Finally, R\&D investment may be constrained by capital market imperfections (i.e., contracting problems between investors and inventors). By its very nature, R\&D investment by external investors engenders information asymmetries and contractual incompleteness between the financier and the research firm (Kamien and Schwartz, 1982; Holmstrom, 1989). Among other concerns, contractual incompleteness can result in (a) inefficient effort provision by the research firm (Aghion and Tirole, 1994; Hellman, 1998a), (b) the potential for hold-up by the research firm of the investors (Anand and Galetovic, 1999) or (c) an adverse selection problem whereby external investors cannot distinguish between profitable and unprofitable projects (Stiglitz and Weiss, 1981; Hubbard, 1998). To the extent that the salience of these imperfections for small firms varies across different industrial segments, $R \& D$ expenditures and the level of technological innovation will reflect this variation. ${ }^{3}$

The goal of this paper is to develop and implement an empirical framework that begins to disentangle these alternative sources of inter-industry variance. Specifically, we derive a test for the presence of variation in the salience of capital and product market imperfections across industrial segments, while simultaneously allowing for controls for the level of technological

Toole, 1999; Hall, 1999).

${ }^{2}$ While several researchers have attempted to document both the extent of inter-industry variation in appropriability and the variation in the mechanisms used to appropriate the rents from innovation in different industries (Levin, et. al., 1987; Cockburn and Griliches, 1988; Klenow, 1996; Cohen, Nelson, and Walsh, 2000), prior research tends to focus on the appropriability conditions facing larger established firms (for which data has been more readily available). Moreover, because the analysis focuses on projects which are themselves funded by the private sector, these prior analyses have not disentangled the relative salience of technological opportunity, capital market imperfections, and appropriability.

${ }^{3}$ Prior empirical work on the impact of capital market imperfections focuses on the sensitivity of R\&D expenditures to measures of capital liquidity (e.g., measures of firm's cash flow), both for broad samples of firms (Hall, 1992; Hao and Jaffe, 1993; Geroski, 1994) as well as for studies specifically focused on smaller firms where capital constraints may be more likely to bind (Himmelberg and Petersen, 1994). However, prior research has not linked capital constraints to the sectoral concentration of R\&D funding. 
opportunity for individual $R \& D$ projects. In so doing, our results shed light on the sources of the concentration of small-firm R\&D financing.

Our test relies on evaluating the empirical relationship between the performance of $R \& D$ projects performed by small firms but subsidized by the Federal government (more specifically, through the Small Business Innovation Research (SBIR) program) and the level of private finance for small firm venture financing in those sectors. ${ }^{4}$ After controlling for technological opportunity, if subsidized project performance is highest in those sectors where private funding is lowest, this suggests that differences in funding across segments are, at least in part, the result of differences in capital constraints. Alternatively, if subsidized project performance is highest in those sectors where private funding is high, this suggests that differences across segments are the result, at least in part, of variation in the level of appropriability.

Consider two extreme examples. First, suppose the only differences across sectors are from variation in the salience of capital market imperfections (i.e., there is no variation in the level of appropriability or technological opportunity). In this environment, the lowest level of private $R \& D$ financing will be associated with sectors most constrained by imperfections in the capital market. As well, the most promising projects that go unfunded by the private sector (i.e., "marginal" projects) will be associated with these same under-funded sectors. If the subsidy program targets these "marginal" candidates, there will be a negative relationship between the sector-specific average performance of subsidized projects and the sector level of private financing.

\footnotetext{
${ }^{4}$ By examining performance differences across subsidized projects, this paper differs from prior attempts to evaluate inter-sectoral differences in the environment for small-firm R\&D. By and large, such studies have analyzed samples that are subject to an important selectivity - they have indeed been funded by the private sector (Mansfield, 1995; Griliches, 1998; Hall, 1988; Hall, 1992; Himmelberg and Petersen, 1994) and so it is difficult to isolate the differences in capital market imperfections from more downstream issues such as the appropriablity regime.
} 
On the other hand, consider an environment in which differences across sectors are driven solely by variation in the level of appropriability. In this case, sectors with the highest level of private funding will be associated with the highest level of appropriability. At the same time, high-appropriability sectors will offer the most attractive "marginal" candidate projects for the subsidy program. Consequently, under this scenario, there will be a positive correlation between average sector-level project performance and the level of private investment at the sector level. As we show in Section III, it is possible to consider variance in both capital constraints and appropriability at the same time: if the SBIR funds projects "on the margin" then, under the simplest functional form, the correlation between subsidized project performance and the level of funding is equal to the difference in the variance associated with appropriability and the variance associated with capital constraints. ${ }^{5}$

We explore these ideas using a novel dataset of SBIR-funded projects. ${ }^{6}$ As described further in Section $\mathrm{V}$, the survey identifies performance measures at the project level and incorporates detailed controls for firm size, organizational and financial structure, and the commercialization strategy associated with each innovation. The main empirical exercise evaluates the relationship between project-level performance and the level of private venture financing in the industrial sector to which each project belongs. Our principal finding is that project-level performance is strongly positively correlated with the level of private venture capital. Even after incorporating various controls (including two distinct measures to control for technological opportunity), a doubling of the level of private venture capital is associated with

\footnotetext{
${ }^{5}$ Section III also highlights several limitations associated with this test (along with potential remedies), including the importance of (a) controlling for technological opportunity, (b) accounting for the SBIR project selection mechanism and (c) the direct impact of subsidy financing on project performance.

${ }^{6}$ As such, our approach differs substantially from prior work on the SBIR (in particular Lerner (1996) and Wallsten (2000)). Both of these prior studies seeks to identify the incremental benefits of an SBIR grant relative to privately funded research; in contrast, we examine the differences across funded firms in order to understand how different segments differ in terms of the environment for innovation for smaller firms.
} 
over a $50 \%$ increase in expected project performance. Simply put, the most successful subsidized projects are in those industrial segments that have attracted a high rate of private investment. Consistent with our framework, we interpret these results as suggesting that industrial sectors vary in their degree of appropriability for research-oriented small businesses; in other words, variation in appropriability helps explain the relative concentration of venture capital activity in a small number of industrial segments.

\section{The Concentration of $R \& D$ and Venture Capital Expenditures}

Our starting point is the concentration of venture financing among industrial segments. Consider first the concentration of privately funded R\&D expenditure. Figure 1A presents the Lorenz distribution of $R \& D$ funding relative to value added across the manufacturing sector of the U.S. economy. ${ }^{7}$ Relative to the distribution of aggregate economic activity (even confined to the manufacturing sector), a small share of sectors (such as the pharmaceutical, computer equipment, and transportation industries) account for most of privately financed R\&D (e.g., the Gini coefficient is .60).

This relative concentration of innovative investment becomes even more pronounced when one examines venture capital financing or the financing of $R \& D$ in small and mediumsized firms. Using data drawn from Kortum and Lerner (1998), Figure 1B compares the relative distribution of venture financing by industrial segment relative to the (already concentrated) privately financed $R \& D$ investment. Though there are difficulties in uniquely assigning venture capital investments into specific SIC-oriented sectors, Figure 1B suggests that, even among

\footnotetext{
${ }^{7}$ All data are drawn from the 1992 NSF Science and Engineering Indicators and are presented in terms of their rank of $\frac{\mathrm{R \& D}_{j}}{\operatorname{VALUE~ADDED}_{j}}$.
} 
$R \& D$-intensive sectors, a very small number receive a very high share of the overall funds from venture capital sources (here the Gini coefficient is .54). ${ }^{8}$ Taken together, Figures $1 \mathrm{~A}$ and 1B suggest that the concentrated nature of investment by small firms is not merely driven by difference in raw technological opportunity (which would presumably be reflected in the aggregate $R \& D$ distribution shown in $1 \mathrm{~A}$ ) but depend on the ability of small firms to attract finance for risky but potentially valuable innovation investments and their ability to translate their technological success into private economic returns (thus accounting for the additional concentration present in 1B). The remainder of this paper develops an empirical framework testing for the presence of two alternative drivers of this "excess" concentration: appropriability and capital constraints.

\section{A Simple Model of Sector-Level Variation in Innovative Expenditure}

This section derives a test for the sources of variation among sectors resulting in the concentrated nature of venture financing activity. Our test relies on the association between the performance of government-subsidized projects and the level of private financing available in different economic sectors. We demonstrate that, if variation in capital constraints is important for understanding differences across sectors, the average performance of SBIR grantees is likely to be negatively associated with observed levels of venture capital funding. This is because the funding mechanism identifies high potential performers only in industries where those are not otherwise likely to be funded. Alternatively, a positive association between average performance and venture capital funding will be indicative of the relative importance of appropriability as

\footnotetext{
${ }^{8}$ Indeed, while economists have mostly ignored this observation, its validity is a widely accepted and welldocumented feature of the venture finance industry (www.ventureone.com). As well, similar concentration is
} 
explaining differences across industries in terms of small firm research financing. To derive this empirical test, we first develop a model of the equilibrium level of private funding for small firm research in the presence of both appropriability and capital constraints and then derive the implications for the performance of subsidized projects. In addition, our discussion highlights several potential limitations (and associated remedies) for our proposed test, including those arising from (a) the importance of controlling for technological opportunity (b) alternative funding mechanism for SBIR project selection and (c) the direct impact of government subsidy on project performance.

\section{Players, Payoffs and Choice Variables}

Our model focuses on the relationship between funding and performance of research projects undertaken by independent research units (each is denoted as an RU). A single RU, $j$, can potentially engage in $R \& D$ for a single project requiring a single unit of capital investment. Capital financing may be provided by two sources: a venture capitalist (VC) or by a government subsidy. We assume that the capital contribution of the VC is contractible and competitive (i.e., there are a potentially large number of homogenous VCs who contemplate financing RU projects). If the project is financed, a commercializable innovation is generated with probability $p . p$ may be endogenous, in that the success probability may depend on either the effort or ability (type) of RU $j$.

If the $R \& D$ project is technologically successful, the innovation creates a total social value, $V_{j}$, of which the RU (and their equity partners) appropriate $v_{j}\left(V_{j}, \gamma_{i}\right)$ where $\gamma_{i}$ parameterizes the 'distance' between $V_{j}$ and $v_{j}$ in industry $i . v_{j}($.$) is assumed to be non-decreasing$ 
in $V_{j}$ and $\gamma_{i} . \gamma_{i}$ therefore measures the level of appropriability in industry $i$. Of course, there are many potential determinants of $\gamma_{i}$, including the strength of intellectual property and ease of technological imitation (Arrow, 1963; Anton and Yao, 1994), the degree of product market competition (Kremer, 1998), and asymmetries among innovators and competitors in the ownership of "complementary assets" necessary for effective commercialization (Teece, 1987; Bresnahan, Stern, and Trajtenberg, 1997). Variation in each of these factors can result in differential levels of appropriability for independent RUs, insofar as each may increase the "wedge" between the private and social returns associated with innovation.

As well, for each industry $i$, there is a distribution of the total social returns across potential projects. Specifically, we assume that each project is drawn from an industry-level distribution that is uniform over $\left[0, \bar{V}_{i}\right]$. By construction, then, a shift in $\bar{V}_{i}$ is equivalent to shifting out the level of technological opportunity in industry $i$.

\section{The Level of VC Funding}

The equilibrium level of private venture finance in industry $i$ will be determined by the measure of projects whose private expected benefits exceed the marginal private cost of project funding. We assume that, for each industry $i$, these costs are determined according to $c\left(F_{i}, \theta_{i}\right)$ where $F_{i}$ is the total level of industry funding, $\theta_{i}$ parameterizes the industry-specific difference between the private and social cost of capital, and $c($.$) is non-decreasing in both F_{i}$ and $\theta_{i}$. That is, the supply curve of capital for RU projects is (potentially) upward-sloping and, relative to the socially efficient schedule, the impact of capital market imperfections is to shift upward the supply schedule of capital.

tabulations available from the authors). 
This is obviously a reduced-form specification; the net impact of imperfections in the capital market reflects more specific contracting hazards between investors and inventors, including (a) inefficient effort provision as the result of imperfect monitoring (Holmstrom, 1989; Aghion and Tirole, 1994; Hellman, 1998a), (b) inefficient grouping of projects with different $v$ as the result of imperfect observability of project quality (Stiglitz and Weiss, 1981) and (c) potential ex-post expropriation of the rents from innovation by the investors as the result of imperfect property rights over the inventor's knowledge (Anton and Yao, 1994; Gans and Stern, 2000). In Appendix A, we demonstrate that, consistent with our characterization, each of these individual effects results in raising the private cost of capital above the social cost of capital; however, since we do not disentangle the differential impact of each of these more nuanced mechanisms in the empirical work, here we aggregate these effects into the single index of the level of imperfections in the capital market, $\theta_{i}$.

The demand for capital from VCs is determined by the distribution of expected private returns for projects, $p v_{j}$, and so will be downward-sloping as the result of the distribution of project quality. The equilibrium level of funding will be determined by the interaction between private capital demand and the upward-sloping marginal cost of funding (see Figure 2). The number of funded projects, $F_{i}$, is determined by the distribution of project value in the industry; the social value of the marginal project is equal to $\hat{V}_{i}=\bar{V}_{i}-F_{i}$. This relationship allows us to derive how the equilibrium level of funding and marginal expected performance relate to the structural parameters of the model:

$$
p \hat{v}_{i}\left(\bar{V}_{i}-\hat{F}_{i}, \gamma_{i}\right)=c\left(\hat{F}_{i}, \theta_{i}\right)
$$


In terms of total funding, $\hat{F}_{i}\left(\bar{V}_{i}, \gamma_{i}, \theta_{i}\right)$ is increasing in $\bar{V}_{i}$ and $\gamma_{i}$ but falling in $\theta_{i}$. That is, an increase in technological opportunity $\left(\bar{V}_{i}\right)$ or appropriability $\left(\gamma_{i}\right)$ shift demand and hence $\hat{F}_{i}$ upwards, while an increase in capital imperfections $\left(\theta_{i}\right)$ shifts supply upward, reducing $\hat{F}_{i}$. Of course, since projects are undertaken only if $p v_{j}\left(V_{j}, \gamma_{i}\right) \geq c\left(F_{i}, \theta_{i}\right)$, the level of private investment will be less than socially desirable as long as there are any capital market imperfections or less-than-perfect appropriability.

Expected marginal project performance $\left(p \hat{v}_{i}\left(\bar{V}_{i}-\hat{F}_{i}\left(\bar{V}, \theta_{i}, \gamma_{i}\right), \gamma_{i}\right)\right)$ will also be sensitive to the degree of capital imperfections and the level of appropriability. While greater capital market imperfections will be associated with higher $\hat{v}_{i}$ (as the result of upward shifts of the capital supply curve along the capital demand curve), lower levels of appropriability will be associated with lower expected marginal project returns (as the result of movement downward along the capital supply curve).

\section{Marginal Project Performance and Private Funding Levels}

These comparative statics allow us to derive our test for the presence of alternative sources of variance across industrial segments. On the one hand, while the expected performance of the "marginal" project in industry $i, p \hat{v}_{i}$, is increasing in the level of capital constraints $\left(\theta_{i}\right)$, low levels of appropriability are predicted to be associated with lower performance levels for the marginal project. On the other hand, both capital and product market imperfections will contribute to lower levels of overall private funding $\left(\hat{F}_{i}\right)$. As a result, after controlling for technological opportunity, the sign of the correlation between private funding and 
marginal project performance provides a test for the presence of variance in either the level of capital constraints or appropriability across multiple economic sectors.

Proposition 1. Consider a set of industries where the level of private funding and marginal project performance are determined according to (1). Then

(a) If $\operatorname{Var}\left(\gamma_{i}\right)=0, \operatorname{Cov}\left[\hat{v}_{i}, \hat{F}_{i} \mid \bar{V}_{i}\right] \leq 0$

(b) If $\operatorname{Var}\left(\theta_{i}\right)=0, \operatorname{Cov}\left[\hat{v}_{i}, \hat{F}_{i} \mid \bar{V}_{i}\right] \geq 0$

In other words, if there is no variance in the level of appropriability (capital constraints), then, after controlling for the level of technological opportunity, the correlation between private funding levels and marginal project performance will be non-positive (non-negative). Consequently, a finding of a positive (negative) correlation allows us to reject $\operatorname{Var}\left(\gamma_{i}\right)=0\left(\operatorname{Var}\left(\theta_{i}\right)=0\right)$

Proposition 1 follows from the fact that if only $\theta_{i}$ varies (and there is no variance in appropriability and we control for technological opportunity), then the industry equilibrium pairs $\left(\hat{v}_{i}, \hat{F}_{i}\right)$ lie along a single capital demand curve. As a result, increasing the level of capital constraints will be associated with increases in the performance of marginal projects alongside decreases in the overall level of funding (and conversely for the case of variance in $\left(\gamma_{i}\right)$.

Moreover, if we are willing to assume specific functional forma for $c($.$) and v($.$) we can$ extend Proposition 1 and derive the structural relationship inherent in the covariance between industry-level R\&D funding and marginal project performance. In the simplest (linear) case, the covariance of $\hat{F}_{i}$ and $\hat{v}_{i}$ is negatively correlated if and only if the variance of $\theta_{i}$ exceeds the variance in $p v($.$) (and vice versa).$

Proposition 2. Suppose that $c\left(F_{i}, \theta_{i}\right)=F_{i}+\theta_{i}$ and $v\left(V_{i}, \gamma_{i}\right)=V_{i}-\left(\alpha-\gamma_{i}\right)$ and that $\bar{V}_{i}$, $\gamma_{i}$ and $\theta_{i}$ are independent random variables and $\gamma_{i} \in[0, \alpha]$. Then the correlation between marginal 
project performance and industry-level funding is a linear function of the difference in the variance of $v($.$) and \theta_{i}: \operatorname{cov}\left[\hat{v}_{i}, \hat{F}_{i}\right]=\frac{1}{(1+p)^{2}}\left(p\left(\operatorname{Var}\left[\bar{V}_{i}\right]-\operatorname{Var}\left[\alpha-\gamma_{i}\right]\right)-\operatorname{Var}\left[\theta_{i}\right]\right)$.

PROOF: For this case, from (1), $\hat{F}_{i}=\frac{p}{1+p}\left(\bar{V}_{i}-\alpha+\gamma_{i}-\theta_{i}\right)$ and, from (1), $\hat{v}_{i}=\frac{1}{p(1+p)}\left(p\left(\bar{V}_{i}-\alpha+\gamma_{i}\right)+\theta_{i}\right)$. Then:

$$
\begin{aligned}
\operatorname{cov}\left[\hat{v}_{i}, \hat{F}_{i}\right] & =E\left[\frac{1}{p(1+p)}\left(p\left(\bar{V}_{i}-\alpha+\gamma_{i}\right)+\theta_{i}\right) \frac{p}{1+p}\left(\bar{V}_{i}-\alpha+\gamma_{i}-\theta_{i}\right)\right]-E\left[\frac{1}{p(1+p)}\left(p\left(\bar{V}_{i}-\alpha+\gamma_{i}\right)+\theta_{i}\right)\right] E\left[\frac{p}{1+p}\left(\bar{V}_{i}-\alpha+\gamma_{i}-\theta_{i}\right)\right] \\
& =\frac{1}{(1+p)^{2}}\left(p E\left[\bar{V}_{i}^{2}\right]-p E\left[\left(\alpha-\gamma_{i}\right)^{2}\right]-E\left[\theta_{i}^{2}\right]-p E\left[\bar{V}_{i}\right]^{2}+E\left[\alpha-\gamma_{i}\right]^{2}+E\left[\theta_{i}\right]^{2}\right) \\
& =\frac{1}{(1+p)^{2}}\left(p\left(\operatorname{Var}\left[\bar{V}_{i}\right]-\operatorname{Var}\left[\alpha-\gamma_{i}\right]\right)-\operatorname{Var}\left[\theta_{i}\right]\right)
\end{aligned}
$$

where the second step follows from the independence assumption.

\section{An Empirical Test for the Presence of Variance in the Level of Appropriability and/or Capital Constraints}

To translate Propositions 1 and 2 into a concrete empirical test, we need to identify measures of the equilibrium pair $\left(\hat{F}_{i}, \hat{v}_{i}\right)$ across different industries. In that regard, given a selection of industrial segments, $\hat{F}_{i}$, the level of private R\&D financing (for small firms), is readily observable. However, if the sample of projects are funded and performed by the private sector, it will be difficult (if not infeasible) to identify a measure for $\hat{v}_{i}$, the performance of the "marginal" project for each industry. Since private $R \& D$ financing is provided to projects which exceed the funding criterion, only a small set will be "on the margin" in terms of funding viability in any given industry. Instead, we propose to use the performance of projects that are subsidized by the government but performed by small and medium sized firms in the private sector as our measure of $\hat{v}_{i}$, namely a set of SBIR-funded projects.

From a public finance perspective, an efficient R\&D subsidy program specifically funds projects that satisfy the social but not the private criterion for investment. As a result, to the extent that a government program funds projects also considered by the private sector, then, 
under efficient funding, subsidized projects will consist of those just below the private funding threshold (i.e., the marginal projects in each industrial segment). Even if the government does not specifically seek to identify marginal projects but offers a funding source which is "less preferred" than private venture finance, then the government will once again end up subsidizing those projects which just miss out on private funding. As well, by examining the SBIR (a subsidy program specifically targeted at $R \& D$ financing for small firms), we implement our test in order to evaluate the constraints on small firm financing (i.e., we examine the covariance between private venture finance for small firms and the performance of SBIR projects). In so doing, our examination focuses on an area where variation in appropriability and capital constraints are particularly important (for small firms) in contrast to the more general pattern of technological opportunity that may be driving the concentration of aggregate R\&D expenditures. Consequently, the performance of projects resulting from a subsidy aimed at small and mediumsized firms provides a useful index of industry-level marginal performance of small firms. While we consider several limitations to this measure (and potential remedies) below, the relationship between the performance of subsidized projects $\left(\hat{v}_{i}\right)$ and industry-level private financing $\left(\hat{F}_{i}\right)$ provides a concrete empirical approach to determining the relative salience of capital constraints and appropriability in explaining the variance of small-firm venture financing across industries.

\section{Limitations and Potential Remedies}

Without further amendment or caveats, it would seem that the proposed procedure provides a consistent test for the hypotheses in Proposition 1 only under relatively stringent conditions: variance in technological opportunity is either absent or controlled for, the 
government-subsidized projects are at the margin of industry performance, and there is no direct impact of the government subsidy on project performance itself. While relaxing each of these assumptions requires a somewhat more nuanced interpretation of our results, we can address each concern so that, while we keep each of these factors in mind, we are able to implement the test implied by Proposition 1 .

First, as Proposition 1 highlights, a consistent hypothesis test for the presence of variance in the level of capital constraints or appropriability is conditioned on a control for the level of technological opportunity. Indeed, traditional evaluations of the sources of R\&D funding are often unable to disentangle the salience of market imperfections from the overall level of technological opportunity. ${ }^{9}$ However, we employ two separate mechanisms to provide a consistent control for the level of technological opportunity for each of the subsidized projects in our sample. As discussed earlier, our analysis focuses on the relationship between the level of private venture financing aimed at small firms and the performance of subsidized projects aimed at small businesses. As such, we are able to include R\&D expenditures by large firms in industry $i$ as a control for the level of overall technological opportunity in industry $i$. For example, in the pharmaceutical industry, the level of funding by established pharmaceutical firms provides a useful measure of perceived technological opportunity $\left(\bar{V}_{i}\right)$ in that industry relative to the impact of market imperfections $\left(\gamma_{i}, \theta_{i}\right)$ specific to (smaller) biotechnology firms. ${ }^{10}$ As well, we employ a direct measure of technological opportunity - a measure of the public

\footnotetext{
${ }^{9}$ This inability to disentangle these factors is made difficult for two distinct reasons. First, most prior analyses focus on the funding and performance of projects which are themselves funded by the private sector and so each project, at least in expectation, has sufficiently overcome the presence of market imperfections to take advantage of market opportunity (see, for example, Griliches and Cockburn, 1988; Hall and van Reenen, 2000). Second, because prior analyses examine all firms within an industry, there is no "reference" group for which market imperfections should be less salient but for which the level of technological opportunity should be similar to the focus group.

${ }^{10}$ Of course, in a specific microeconomic environment, smaller and larger firms may have differential incentives to respond to a given technological opportunity (perhaps because of incumbency, scale economies, or the like).
} 
"stock" of scientific and technological knowledge associated with each project in the sample (in the tradition of Rosenberg (1974) and Adams (1990)). Between these two measures, our analysis provides a set of (reasonably) consistent controls for technological opportunity.

Second, our proposed implementation to test Proposition 1 is based on the assumption that subsidized projects are "marginal" - those projects in a given industrial segment just below the threshold of private funding. Of course, the subsidy program could use other selection criteria for allocating funds. For example, if projects are selected to ensure the political success of the program, then the subsidized projects may be "cherry-picked" - the best possible projects available to program administrators rather than the set which are socially but not privately worthwhile. ${ }^{11}$ On the one hand, the possibility of cherry-picking qualifies our interpretation of the results. Specifically, under a cherry-picking selection mechanism, the specification continues to provide a consistent test for the existence of variation in the level of appropriability across sectors but becomes a less powerful test for identifying the impact of variance in capital constraints. While a marginal project selection mechanism "balances" the impact of variation in appropriability with the impact of variation in capital constraints, a regime that selects only the "best" projects provides the most powerful test about appropriability at the expense of being able to identify the impact of capital constraints at all. On the other hand, even if project administrators are attempting to cherry-pick projects, they may be greatly limited in that strategy if subsidized funding is a less preferred source of capital than private venture financing. For example, whereas the usual delay between application and grant of a subsidy is several months, venture financiers can immediately fund projects that they deem worthwhile. As well, VCs

However, at an industry level, there is likely a positive correlation between the overall incentives of these two classes of firms, and so we abstract away from these nuanced effects in the present analysis. 
provide additional services beyond financial capital, including access to a network of contacts and expertise in managing research-oriented start-up organizations (Stuart, Hong \& Hybels, 1999; Hsu, 2000). Indeed, most of the respondents in our sample of SBIR firms reported (qualitatively) that they would have preferred to attract venture finance to their projects if it had been available to them. As such, we interpret our results both (a) keeping in mind that the possibility of cherry-picking accentuates the impact of variance in appropriability in terms of the estimated parameter and (b) that it is likely that SBIR-funded projects may in fact tend to be relatively marginal projects, at least at the time of the application to the SBIR program, due to funding preference of private entrepreneurs.

Third, even if the government is selecting projects that are marginal from the perspective of the private sector, the program itself may have a direct impact on the performance of the subsidized projects that impact the salience of the test. Indeed, by construction, the SBIR alleviates the capital constraints facing funded firms. In contrast to the tradeoff that emerges between the provision of incentives and the taking of equity in the analysis of private investment, the SBIR extract neither equity nor debt from the grantee. In fact, quite the opposite. The incentives to perform the research are preserved and incentives to divert the fruits of research away from equity holders are minimized. However, as a hands-off subsidy, SBIR grants cannot alleviate product market imperfections or the lack of technological opportunity in a given field. If intellectual property rights are weak in a given area, SBIR funding cannot overcome this general bias. ${ }^{12}$ Thus, similar to the project selection mechanism, the SBIR program itself likely reduces the power of the test for identifying the impact of variance in capital constraints (as

\footnotetext{
${ }^{11}$ Indeed, Wallsten provides evidence that SBIR administrators in fact do attempt to choose the "best" projects and interprets his evidence to suggest that the SBIR funds many projects which would have received private funding anyway (Wallsten, 2000).
} 
subsidization overcomes some of these constraints) and increase the power of the test for variance in the level of appropriability (since the SBIR does not affect sector-level differences along this dimension).

Finally, while novel and informative, the proposed test should be interpreted conservatively. Even under the best of circumstances, the procedure can only reject a hypothesis of no variance in the level of appropriability (or capital constraints); rejecting this zero-variance hypothesis along one dimension (e.g., appropriability) does not preclude the presence of variance along the other dimension. Indeed, Proposition 2 suggests that, under the simplest functional form and marginal funding, the estimated parameter will be equal to the difference in the variances and so we interpret our results so that evidence in favor of one source of variance by no means rejects variance along the other dimension. Moreover, while the model allows for a balanced test between the variance associated with capital constraints and appropriability, it is likely that the test will be more powerful for finding evidence for differences in appropriability; the project selection mechanism and the incentive effects of the program mitigate against finding direct evidence for capital constraints.

\section{The SBIR Program and R\&D Investment by Small Firms}

This paper uses Proposition 1 in order to evaluate how an evaluation of the performance of government-subsidized small R\&D-intensive firms helps us understand the concentration of research funding across industries and technology segments. To do so, we exploit data about projects funded by the Federal government's SBIR, the largest individual source of R\&D

\footnotetext{
${ }^{12}$ Indeed, while VC funding may provide non-pecuniary value to the firm through managerial expertise or access to a network of contacts, the SBIR focuses on funding technology development per se and contributes essentially no additional commercialization services.
} 
financing for small to medium-sized firms in the United States. SBIR funding provides a unique and informative source of variation in the funding of small, research-oriented firms. First authorized as an NSF program in 1982, the SBIR program requires that all Federal agencies that support a minimal level of R\&D activity are required to set aside a certain percentage of their funds for extramural grants to fund R\&D projects by small business. ${ }^{13}$ The principal legislative goals of the program are to:

(a) increase the commercialization rate of innovations resulting from Federal research,

(b) enhance the 'competitiveness' of small firms in technology-intensive industries; and

(c) enhance the participation of small firms as well as women and minority-owned businesses in the Federal contracting process (GAO, 1995).

As described earlier, the economic impact of the program is to alleviate some of the capital constraints facing funded firms while having no direct impact on the product market environment. However, from a political perspective, the program's support seems to derive in part from (ever-increasing) political demand to focus R\&D expenditures towards more near-term development projects and to areas which have a clear relationship to medium-term economic growth (Cohen and Noll, 1993). Combined with political rhetoric that simply assumes that research-oriented start-up firms are the engine of long-term economic growth, and that such firms face a severe "funding gap" arising from the unwillingness of investors to shoulder the risks of early-stage financing, the SBIR has been a popular program whose scope has been consistently expanded since its inception (GAO, 1995). Indeed, during the 1990s, the SBIR was the single largest source of early-stage R\&D financing for small firms in the United States with annual expenditures over $\$ 1$ billion.

\footnotetext{
${ }^{13}$ This percentage has varied over time (from 1.25 in the 1980 s up to $2.5 \%$ as of 1997). As well, the SBIR defines a small business as a US-owned firm with less than 500 employees. Further details of the SBIR are discussed extensively in GAO (1995), Wallsten (1998), and Lerner (1997).
} 
Despite its political support, the program has been somewhat controversial. In part, this is because neither the legislative nor regulatory rules governing the program mandate the program fund projects on the margin (which would determine performance according to the first part of Proposition One). As highlighted dramatically by Wallsten (2000), the program's funding guidelines seem to focus on funding the most attractive grant applications from either a technical or commercialization perspective. ${ }^{14}$ Indeed, perhaps as a consequence of this selectivity, Lerner finds that firms funded by the program do tend to have an accelerated rate of growth compared to similar firms (Lerner, 1997). However, Lerner emphasizes that this "boost" to firm-level growth seems to be localized according to the location or technology focus of the firm, a contention that our framework implicitly revisits and explores in much greater detail.

More generally, we refocus analysis of the SBIR away from program assessment per se and towards the exploitation of two structure of the SBIR to evaluate the sources of R\&D concentration. First, because the program is administered through a variety of Federal agencies (Agriculture, Defense, HHS, etc.), whose missions span the scope of the economy's activities, the expenditures of the SBIR program are much more widely dispersed (across industries and technological areas) than privately funded R\&D. This wedge between SBIR expenditures and private funding is particularly salient if one focuses on investment or R\&D expenditures specifically for small (or venture-backed) firms. In other words, a specific if unintended contribution of the SBIR program is to expand the supply of capital to research-oriented, smaller firms to a set of industries and technologies which, for one reason or another, do not currently attract high levels of such funds. As a result, the program is extremely useful for identifying

\footnotetext{
${ }^{14}$ As a result, the main focus of prior research (GAO, 1995; Lerner, 1997; Wallsten, 1998; 2000) has been on the assessment of the marginal contribution of SBIR funding (and government venture capital more generally) to the performance of subsidized firms. Towards this goal, these analyses are framed in terms of the counterfactual of the expected behavior or performance of these firms, in the absence of the subsidy program. Indeed, both Lerner (1997)
} 
projects across a set of industrial segments that vary greatly in terms of their level of private venture financing. Second, as discussed earlier, the use of a subsidy program (in contrast to examining privately funded projects) allows, in principle, for the identification of projects in each industrial segment which are socially but not privately worthwhile and so are on the margin of the funding threshold. While it is possible that the program does potentially experience some cherry-picking (which mitigates against this benefits), the fact that SBIR funding tends to be a less "preferred" source of external capital suggests that we the use of subsidized projects are a superior sample for performing our test (relative to prior work which examines projects which are themselves funded by the private sector).

\section{Data}

This paper presents results from a novel dataset of 100 projects funded by the SBIR since 1990. The data were gathered via a field-based proprietary survey conducted by the authors. This project-level data was then supplemented with public data on each firm's patenting behavior, SBIR grant history, and covariates related to the industry, business segment, and scientific underpinning associated with each project. In this section, we first review our procedure and the elements of our survey (highlighting the sample selection and data gathering process) and then review the summary statistics for the sample (Table 1 includes the definitions of all the variables used in the analysis; Table 2 provides means and standard deviations).

and Wallsten (1998; 2000) focus their results around the comparison of a group of SBIR-funded firms and a "matched sample" of firms who are observationally similar ex ante but who do not receive SBIR funding. 
Survey Data Sources and Sample Selection Method

The data is drawn from several sources; most importantly a survey conducted between December and February 1999 (see Appendix B for a copy). ${ }^{15}$ The sample is drawn from a list (compiled by the Small Business Administration) of the (approximately) 200 largest historical beneficiaries of SBIR grants. ${ }^{16}$ For survey participants, we requested information about their most successful project funded by the SBIR (for most firms, there was only one (or at most two) SBIR-funded projects which the firm considered technologically successful). By focusing on projects that overcame the substantial technological hurdles associated with innovation, the data provide information about the relative economic returns of projects in different industries that are at least successful in a technical sense.

At the firm level, we collected background information on the organization's employees and promotion policies; financial information about corporate ownership, expenditures and revenues; and corporate governance. At the project level, each company was asked to provide information on the commercialization and financing history of the technology project, including revenues through sales and licensing of the technology, the importance of the technology in achieving various goals of the firm, key personnel involved in setting the commercialization strategy of the company, and information about the commercialization strategy itself. ${ }^{17}$

\footnotetext{
${ }^{15}$ Along with a similar survey of the commercialization histories of venture-backed firms, the data from this survey are being used to study a variety of phenomena associated with the incentives, strategies, and performance of research-oriented start-ups and, in particular, on the impact of the Federal SBIR subsidy on each of these issues.

${ }^{16}$ The overall response rate to the survey was approximately $50 \%$. Firms contacted but not responding seemed to be randomly mixed between firms not having a commercial product and those too busy or not willing to respond. Within the organization, the respondent was typically one of the following individuals: the director of R\&D, the director of sales or marketing, or the CEO. Most of the surveys (approximately 75\%) were filled out over the telephone, with the balance either faxed or mailed back. All respondents were guaranteed that their individual responses would be kept confidential.

${ }^{17}$ Whenever possible, we used publicly available databases to verify information from the survey responders. For example, we verified the number of patents assigned to each organization through both the US Patent and Trademark Office's web site and the IBM patent database.
} 
From this survey, we construct both project-specific and firm-specific variables (see Table 1 for definitions). First, we define the project-level variables. We define performance in terms of the aggregate annual revenues from product sales, licensing, and intellectual property exchanges (REVENUE 98). ${ }^{18}$ For each project, we identify the number of PATENTS awarded since the grant as well as the project-level SBIR AWARD SIZE (from the USPTO and the Small Business Administration, respectively). In addition, we identify all firms who receive at least some of their overall revenues not through direct product market sales but through licensing arrangements or intellectual property sales. We denote these firms COOPERATORS insofar as nearly all of these firms are involved in cooperative contracting with more established product market incumbents; it is useful to note that this cooperative behavior is in lieu of competition with the same firms who have arranged to "buy out" the SBIR awardees' product market position (Anton and Yao, 1994; Gans and Stern, 2000; Gans, Hsu, and Stern, 2000). We also include several dummy variables, which denote the technology, product and customer base types of each project (UPGRADE, MADE-TO-ORDER, NOVEL SYSTEM, and LARGE CUSTOMER BASE). Finally, we calculate one measure of overall product development efficiency (TIME-TO-MARKET) that is simply the overall time from initial product conception to the first sale of this product to any customer (either directly or through licensing).

As well, we include several firm-specific variables that describe the more general financial and organizational structure of the firm. In terms of the measurement of performance, a portion of our analysis is organized around the determinants of current firm size (EMPLOYMENT 98). We use the initial value of this measure as a key control in most of our empirical analysis (BASELINE EMPLOYEES), in order to control for the initial size of the firm.

\footnotetext{
${ }^{18}$ All of the qualitative results are robust to using the data on total project revenues (indeed, they are highly correlated). However, this would further reduce the number of usable surveys by approximately one-third.
} 
As well, the analysis examines variables related to financial structure, VC EQUITY SHARE and INSIDER EQUITY SHARE. The difference between these is while the first confirms the potential importance of the "certification" hypothesis (SBIR grants lead to VC funding which leads to overall performance), the latter allows us to capture the pure associated between performance and maintaining a closely held organization. Similarly, FOUNDER CEO proxies for the overall entrepreneurial culture and authority structure of the firm.

\section{Sources and Definitions of Industry and Segment-Level Variables}

A critical element of the analysis is the relationship of project-level performance to measures of private and public investments in the industries, technology segments or scientific areas associated with each project. Specifically, we want to distinguish three concepts: overall investment in businesses or $R \& D$ by small firms, aggregate private $R \& D$ in the project's industrial area, and the scientific and engineering opportunities present in the technological areas inherent in the project.

To capture the first, we assigned each project to one of eleven technology segments identified by Venture One (see Figure 3A). For each segment, we measure the VC FUNDING STOCK as the (undiscounted) sum of venture investing in that segment between $1985-1992$. We also present results for the VC CAPITAL FLOW, which are composed exclusively of the 1992 disbursements. We also assign each project (firm) to a single three-digit SIC; the NSF Science and Engineering Indicators provides data for each SIC on SIC-LEVEL R\&D EXPENDITURES, SIC SALES, and SIC-LEVEL SMALL FIRM R\&D EXPENDITURES. Finally, we measure the project's association with scientific or engineering opportunity by constructing a SCIENCE STOCK for each project. First, we assigned each project to one or 
more scientific and engineering fields (out of a total of 14). In contrast to the mutually exclusive nature of the prior variables, the science base of each project can be composed from multiple sources. For each area (e.g., physics or chemical engineering), we computed the (discounted) Federal Funding stock in that area (equal to 1990 FUNDING + .81988 FUNDING +.61986 FUNDING). Each project's SCIENCE STOCK is simply the sum of the individual field-level stocks for fields associated with that project.

In addition, we attempt to provide additional controls for the environmental heterogeneity among firms by including a number of variables from the survey that attempt to capture the firm's perception of the appropriability environment relevant for their specific project. Specifically, we include several variables that relate to the relative importance of differences source of intellectual property (PATENTS, SECRECY, SPEED TO MARKET), each of which is measured as a 5-point Likert scale variable. As well, we include several (five-point Likert scale) variables measuring the importance associated with the control of different complementary assets (MANUFACTURING, DISTRIBUTION, BRANDING, SERVICING).

\section{Summary Statistics}

Out of a total 100 responses, 74 were fully usable for the empirical work reported here. ${ }^{19}$ However, for most of the analysis, we exclude the small number of observations (3) that were clearly so-called SBIR "mills"; these organizations have a much more diverse research portfolio from the rest of the sample and also have a different relationship with funding agencies. This leaves us with 71 total observations for the majority of our analysis.

\footnotetext{
${ }^{19}$ Most of the non-responses were because of non-reporting of all 1998 revenues (e.g., sales reported but not licensing revenue). We have checked our results including all results, even those for whom the data was incomplete; the qualitative results are unchanged.
} 
Among these 71, the average project reports approximately 6.5 million dollars in revenue, compared with an average award size of 1.5 million (but note the high standard deviations associated with each). As well, these organizations seem to be highly productive in a technical sense. On average, each has been issued over 9 patents that were applied for since the first SBIR grant associated with the specific project here (all chosen projects have their first funding date after 1990). In addition, almost a third of the sample earns at least some its revenue through cooperative licensing or IP exchanges (most often with product market incumbents). As well, the average commercialization length of projects is a little over four years, though some outliers in part drive this (from biotechnology and the like). Finally, at the firm level, while most of these organizations are quite small at inception (35 employees on average), they tend to experience substantial growth over time (the average firm has nearly 90 employees by 1998). ${ }^{20}$

As suggested earlier, the principal empirical exercise of this paper will be to relate project-level performance measures (REVENUE 98 and EMPLOYMENT 98) to segment-level measures of private investment activity and the technological environment. Figure 3 presents the distributions of the three principal measures we use to capture these effects: 1992 VC FUNDING STOCK, SCIENCE STOCK, and SIC-LEVEL R\&D EXPENDITURES. Each of these measures provides a distinct way of capturing the degree of environmental heterogeneity facing different SBIR-funded projects in terms of the level of technological opportunity and realized private investment activity. Whereas the VC FUNDING STOCK (Figure 3A) measures the skewed distribution of entrepreneurial activity and is divided into several segments which do not precisely map into the traditional SIC classification, Figure 3B and 3C measure differences in

\footnotetext{
${ }^{20}$ As well, in terms of the internal organization and finance of the firms, over $50 \%$ of equity is retained by insiders; perhaps surprisingly, while $25 \%$ of the sample had attracted some form of $\mathrm{VC}$ or "angel" financing, the equity share of these investors is quite small (the average level of equity held by these outside investors across the full sample is less than $7 \%$ ). In addition, in nearly $60 \%$ of the firms, the CEO is one of the original founders of the firm.
} 
investment in alternative scientific and engineering fields upon which many of these innovations draw and differences across sectors in terms of aggregate R\&D expenditures, respectively. Whereas SCIENCE STOCK and R\&D EXPENDITURES will tend to be sensitive to differences across sectors in terms of technological opportunity, only VC FUNDING STOCK will be sensitive to the differences across sectors in terms of the degree of appropriability or the salience of capital market constraints facing small research-oriented firms. Consistent with the SIC-level motivating statistics we presented in Table II, Figure 3 highlights both the skewed nature of both venture financing and $R \& D$ funding (e.g., telecommunications, medical care technologies, and software make up over $60 \%$ of the aggregate 1992 VC FUNDING STOCK).

In terms of their overall summary statistics, while the VC FUNDING STOCK is measured as the cumulative investment in given areas over 8 years, one can see that the aggregate average level of SCIENCE STOCK and R\&D EXPENDITURES are considerably higher, particularly given that SCIENCE STOCK depends on the summation across three years of investment and R\&D EXPENDITURES is measured from a single cross-section. As well, the Appropriability Mechanism measures (control variables for the environment) are each Likert measures; not surprisingly, the mean of each varies from a little above 3 to just over 4 .

\section{Empirical Results}

We now turn to our evaluation of the principal hypotheses of this paper (recall Proposition 1). Specifically, we are concerned with the degree of variation across sectors in technological opportunity $(\operatorname{Var}(\bar{V}))$, the degree of appropriability $(\operatorname{Var}(\gamma))$, and the relative salience of capital constraints $(\operatorname{Var}(\theta))$. Our empirical test provides evidence about the relative salience of these factors in explaining the large differences in R\&D funding for small firms 
across industries that we highlighted in Section II. Specifically, we test for the relationship between project-level performance and the level of private investment in each project's industry or technological segment, controlling for project-specific or firm-specific factors that also may affect performance. In Tables 3-5 and Figure 4, we present our main finding from this analysis: controlling for project-level, firm-level and other environmental characteristics, revenue is increasing in the level of venture capital funding for small firms in a given technology segment and, more tentatively, in the science stock associated with a given technology. In contrast, performance is not statistically related to overall $R \& D$ investment in a given area or the overall size of an industrial segment. These basic findings are robust to several quite stringent tests of robustness, including the inclusion of additional controls for appropriability, project-level and firm-level factors, as well as variation in the measurement of the level of financing for small research-oriented firms (some of these results are presented in Appendix C). As well, in Table 6, we show that there is also a positive relationship between an alternative measure of performance (EMPLOYMENT 98) and the industry-specific level of venture financing.

\section{The Performance of SBIR-funded Development Projects}

We begin in Tables 3 with the relationship between L REVENUE 98 and each of the alternative measures of private investment and technological opportunity. The most striking result is that, whereas SCIENCE STOCK, SIC R\&D EXPENDITURES, and SIC SIZE are uncorrelated with project-level performance, 1992 VC FUNDING STOCK is both statistically significant and quantitatively important: doubling the level of venture funding in an industrial segment is associated with over a 50\% increase in measured revenue (see (3-1)). As well, in (35), we demonstrate that our principal result concerning the VC FUNDING STOCK is robust to 
the inclusion of the alternative measures of the segment-level environment (which remain themselves insignificant and lower in magnitude). When considering these results, it is useful to recall that the inclusion of SCIENCE STOCK and SIC R\&D EXPENDITURES allow us to distinguish between measures of overall technological opportunity and variation in the level of appropriability or capital constraints impacting small, entrepreneurial firms.

Figure 4 dramatically illustrates this finding. While average project revenue is closely associated with the level of venture financing by segment (indeed, the lowest four segments have average performance levels strictly below the upper four segments), the performance of the SBIR projects seems, at best, to be negatively associated with aggregate R\&D expenditures (which is driven primarily by expenditures by larger firms in each industry. In other words, under the logic of Proposition 1, these results suggests the presence of differences across industrial segments in terms of their appropriability environment (i.e., $\operatorname{Var}(\gamma)>0$ ), even after incorporating two direct measures capturing variation in technological opportunity across segments.

While the sample size is limited, these results provide strong evidence in terms of the presence of variation in appropriability. However, it is important to recall that the results do not reject variation in capital constraints; instead, the impact of variation from appropriability outweighs the impact of variation from capital constraints in these data. Given some of our earlier concerns about the details of the project selection mechanism (i.e., the possibility of cherry-picking) and the impact of subsidized funding on project performance (which will tend to ameliorate the impact of capital constraints), it is perhaps not surprising that our main empirical findings are in support of variation in the level of appropriability. By itself, this is an important finding: we are not aware of prior quantitative evidence demonstrating that the sources of 
concentration in venture financing is driven by segment-level differences in the level of appropriability.

Of course, it is possible that these results are in fact being driven by more "project-level" factors that outweigh the impact of the segment-level variation. Table 4 therefore extends the analysis of the determinants of REVENUE 98 by focusing on the robustness of the VC FUNDING STOCK result to the inclusion of various project-level, firm-level, or alternative environmental controls. In (4-1), we include the simplest "control," the level of initial employment at each firm. In some sense, this very simple measure should capture some degree of the heterogeneity among firms in terms of their initial conditions in terms of generating products associated with a given level of revenue; however, its inclusion does not impact our main result at all. We then extend our analysis is (4-2) and (4-3) by including a number of alternative control variables, associated with the firm's perception of the appropriability environment and project-level controls, respectively. At one level, the results from this analysis are interesting in their own right: while revenues are increasing in the technological quality and product development efficiency of the project (PATENTS, UPGRADE and TIME TO MARKET respectively) and whether firms "cooperate" with more established firms (note this could be in part the result of the selectivity of projects which are attractive for licensing), revenues are relatively unrelated to the Likert measures of the appropriability environment facing individual firms. However, the more important finding from Table 4 is that the coefficient associated with VC FUNDING STOCK remains roughly the same magnitude and statistically significant, despite the large number of control variables included and given the relatively small number of observations in the sample. Indeed, in (4-4), we include all of the control measures simultaneously with no impact on the underlying result regarding the VC FUNDING STOCK 
variable. Once again, given the logic of Proposition 1 (and the associated caveats about the relatively small sample size and the imperfect controls for project selection), these results suggest variation across sectors in terms of the degree of appropriability facing small firms, and that such differences are reflected in the ability of subsidized firms to earn returns on their innovations in specific industrial segments.

In Table 5, we turn back to the more general comparison between the VC FUNDING STOCK variable and measures which more closely correspond to technological opportunity (SCIENCE STOCK and SIC R\&D EXPENDITURES). Specifically, in (5-1) and (5-2), we regress REVENUE 98 on each of the alternative measures (SCIENCE STOCK and SIC R\&D EXPENDITURES, respectively), including all of the controls considered in Table 4. Interestingly, with these controls in place, the magnitude of the coefficient associated with SCIENCE STOCK increases substantially and is statistically significant (SIC R\&D EXPENDITURES remains both relatively small and statistically insignificant). However, when, in (5-3), we include all of these variables together, the principal result associated with VC FUNDING STOCK remains robust, as does the SCIENCE STOCK result. In other words, even after we control simultaneously for various project-level controls as well as measures associated with technological opportunity and aggregate R\&D expenditures, the highest performing SBIRfunded projects tend to be associated with those industrial segments with high rates of venture capital funding. ${ }^{21}$ While such a result may be interesting in terms of SBIR evaluation per se, perhaps we highlight the economic implication of this finding: such covariation exists when

\footnotetext{
${ }^{21}$ Appendix C (Tables C-1 and C-2) further establish the robustness of the VC FUNDING result. In C-1, we include additional firm-level covariates, including measures of the financial organization of the firm, as well as additional environmental covariates associated with the geographic location of the firm. As before, while the SCIENCE STOCK variable is only significant in some specifications, the VC FUNDING STOCK remains significant at a similar magnitude. Finally, in C-2, we consider alternative sample selection schemes such as mandating that we only include projects whose 98 REVENUES are greater than the size of their SBIR grant or including the SBIR "mills" in the analysis. As before, our main qualitative results are unchanged.
} 
differences across sectors are the result of differences in the level of appropriability facing small, entrepreneurially oriented firms.

Finally, in Table 6, we compare our results regarding REVENUE 98 to an alternative analysis focused on the determinants of firm-level employment (EMPLOYMENT 98). In some sense, this analysis is more directly comparable to the analysis pursued by Lerner (1997), in that Table 6 focuses on the determinants of firm-level performance among SBIR-funded firms. The analysis is straightforward and echoes our earlier finding: while employment growth seems to be relatively unrelated to environmental measures associated with SCIENCE STOCK or SIC R\&D EXPENDITURES, there is a quantitatively important and statistically significant relationship between EMPLOYMENT 98 and VC FUNDING STOCK, even after controlling for BASELINE EMPLOYMENT (as well, this result is relatively robust to the inclusion of various controls, similar to the earlier analysis). In conjunction with our earlier findings regarding REVENUE 98, Table 6 provides additional evidence that there is a robust positive relationship between the performance of SBIR-funded projects and segment-specific levels of venture activity, consistent with the presence of differences across sectors in the appropriability environment facing small research-oriented firms.

\section{Conclusions}

The main conclusions of this study are the result of its core quantitative finding: SBIR project performance is highest for those projects in industrial segments which themselves receive the highest level of venture financing. Such a finding should be of some direct interest to policymakers: if program administrators are given strong incentives to identify projects with the highest performance, then there may be pressures to focus SBIR funding precisely on those 
segments for which venture financing is readily available. Or, from another perspective, the fact that the SBIR program is run through a variety of different agencies may have the (unintended but) beneficial effect of increasing the availability of funding to precisely those segments of the economy where small-firm research faces the highest hurdles, either in terms of appropriability or capital constraints.

More generally, however, this finding allows us to begin to disentangle the relative salience of alternative sources of the concentration of venture financing. While we view our results as suggestive rather than definitive, to our knowledge, this is the first evidence for the importance of variation in appropriability in helping to understand the concentration of $R \& D$ among a small number of industrial segments. Specifically, whereas most prior analyses have had difficulty distinguishing between the response to overall technological opportunity and the level of appropriability, our focus on specific technologies being commercialized by smaller firms subsidized by the U.S. government provides extremely useful controls: patterns of aggregate spending by larger firms and the stock of scientific knowledge used by individual projects. More generally, our results suggest that rather than simply being the result of "herding" by venture capitalists in response to diffuse priors about technological opportunity, our evidence suggests that the economy seems to offer small "pockets" where the appropriability regime (and the level of technological opportunity) facing small, research-oriented start-ups is particularly favorable. Indeed, understanding how such pockets emerge is a promising area for further study.

As well, the specific interpretation of our results can be tied more specifically to policy. Whereas the SBIR is focused on overcoming the "funding gap" for small, research-oriented firms, our results suggest that there may be some benefits from also addressing the strength of the appropriability regime facing small firms. At least in part, the low level in funding for small 
firm research in some areas may be the result of specific (and potentially remediable) weaknesses in the appropriability regime facing small firms, such as the availability of intellectual property or antitrust rules which limit the ability of smaller firms to access the complementary assets required for commercialization in a competitive market.

As we have emphasized several times, our results are provocative but not the final word. Even beyond issues such as the sample size, our approach only allows us to estimate a "reducedform" parameter and so our evidence in favor of variance in appropriability comes at the expense of simultaneously identifying the salience of capital constraints. As well, while our results concerning appropriability are consistent even if the project selection mechanism satisfies a "cherry-picking" regime and there are direct impacts of the program on project performance, distinguishing among the separate effects of each of these factors seems important. Perhaps a careful integration of the program evaluation methodologies of Wallsten and Lerner with the within-program evaluation pursued here will allow for more nuanced examination of both the role played by market imperfections in shaping the level and productivity of small firm innovation and the role played by government policy in alleviating these market imperfections. 
Figure 1A. Concentration of Private R\&D Expenditures

vs. Value-added

(Lorenz curve, millions of 1992 dollars)

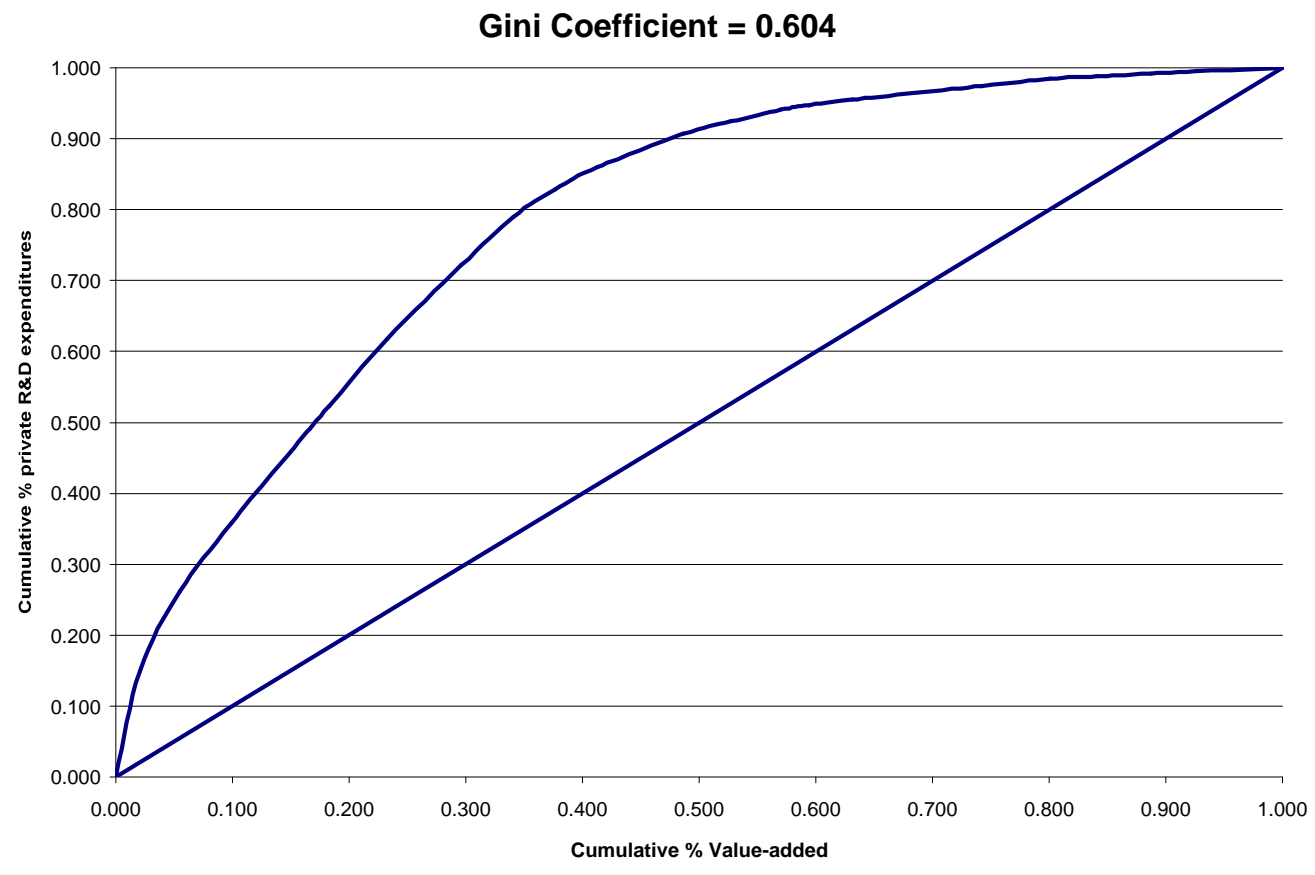


Figure 1B. Concentration of VC Disbursement

vs. Private R\&D Expenditures

(Lorenz curve, millions of 1992 dollars)

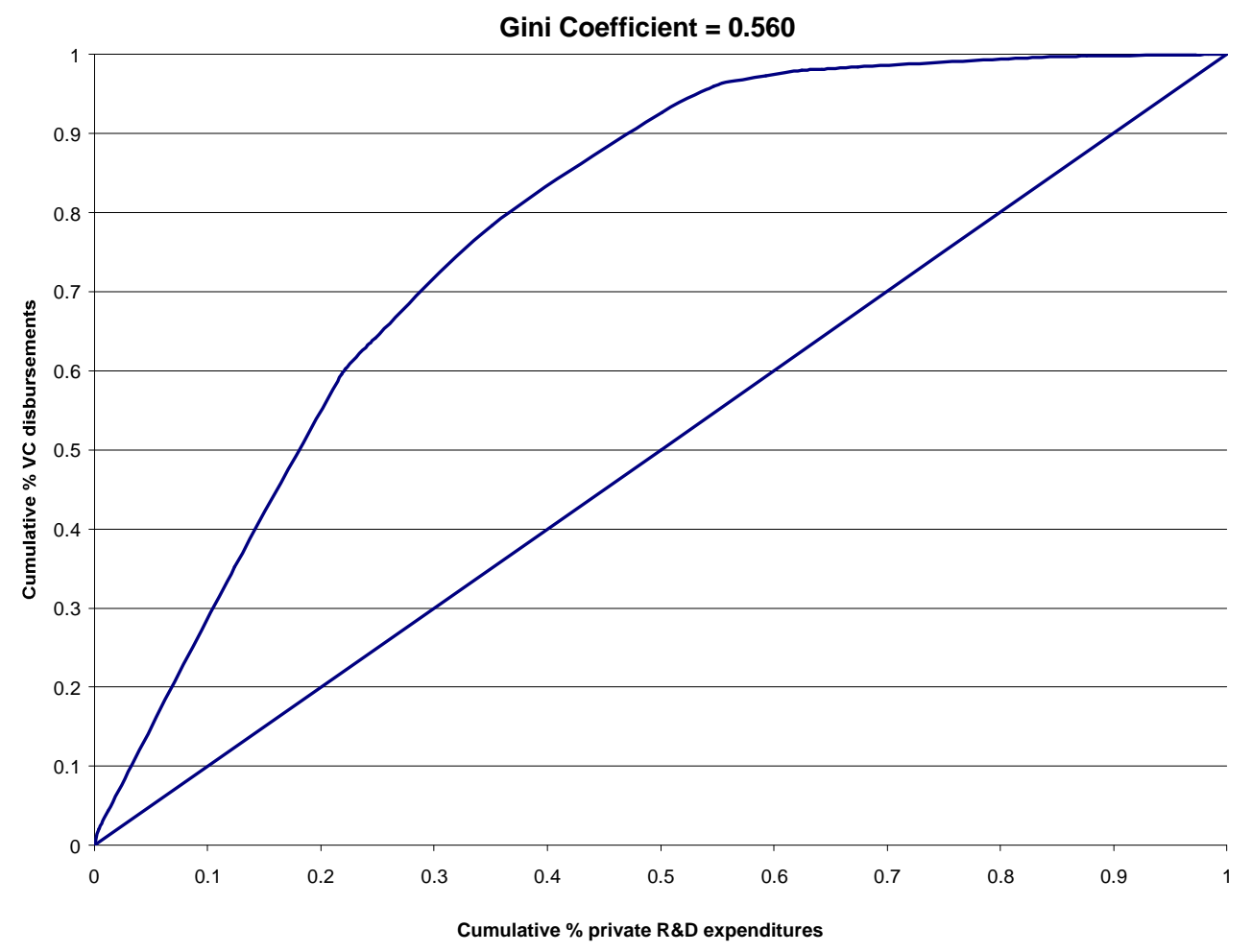


Figure 2: Equilibrium Industry Funding

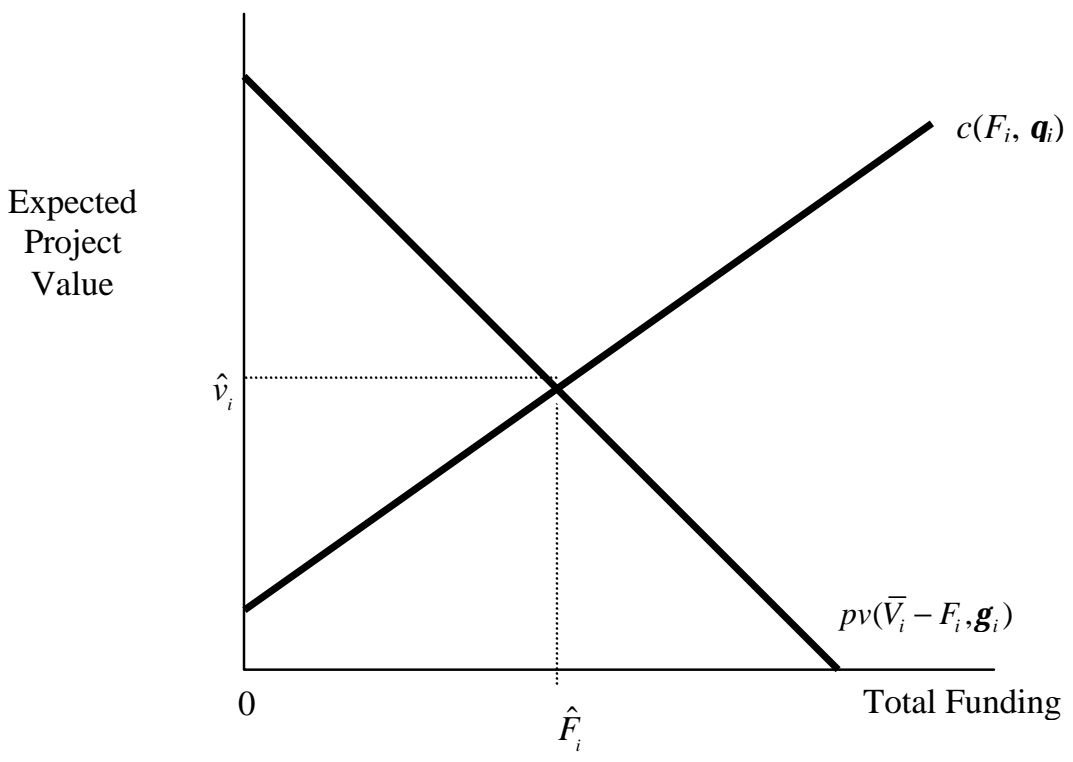


3A. VC Funding Stock, 1992

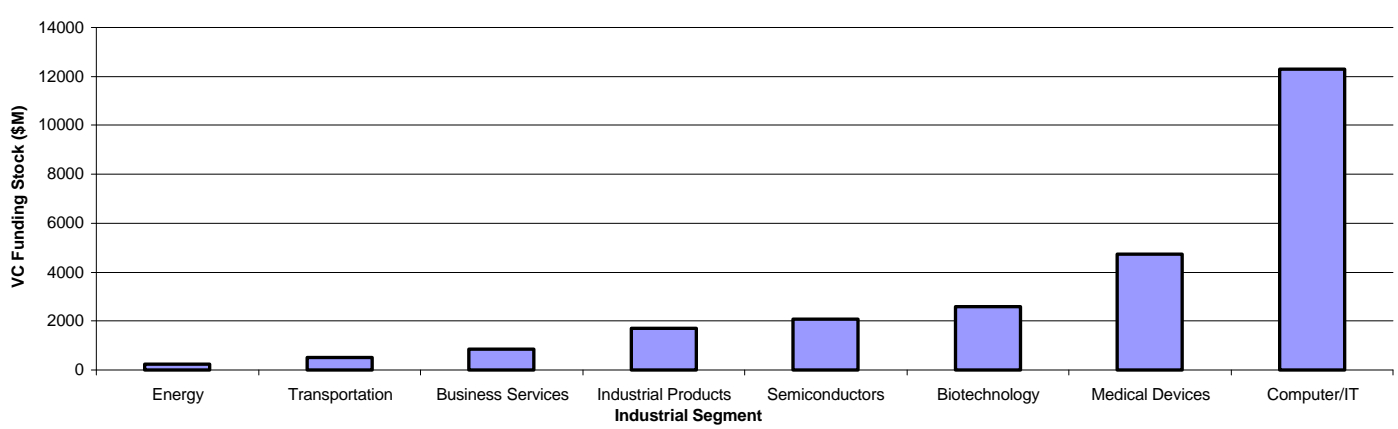

3B. R\&D Expenditures, 1993

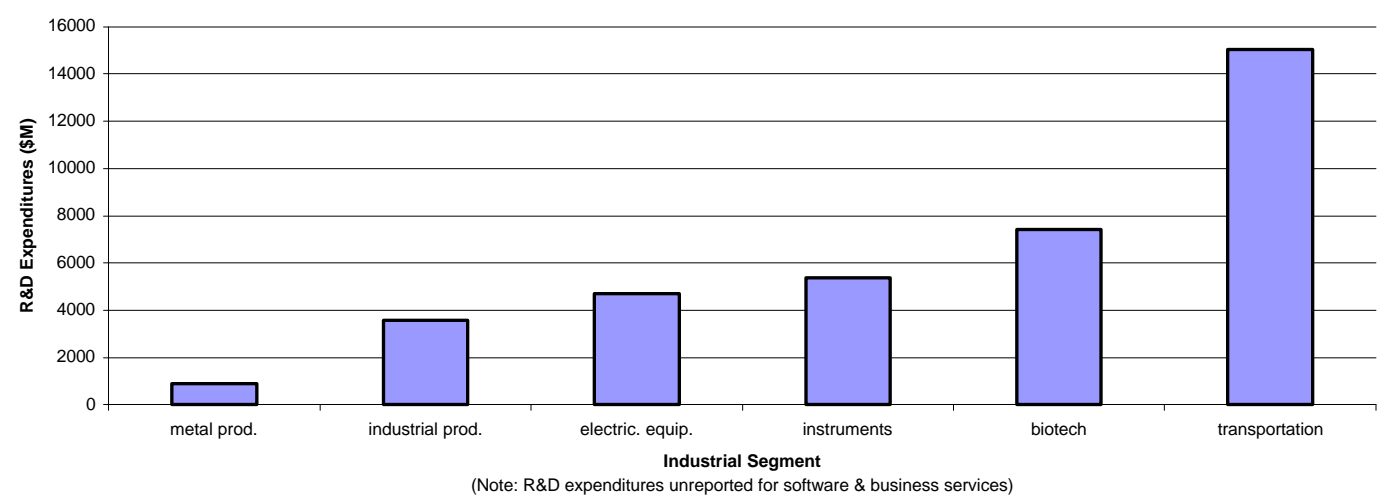

3C. Science Stock, 1990

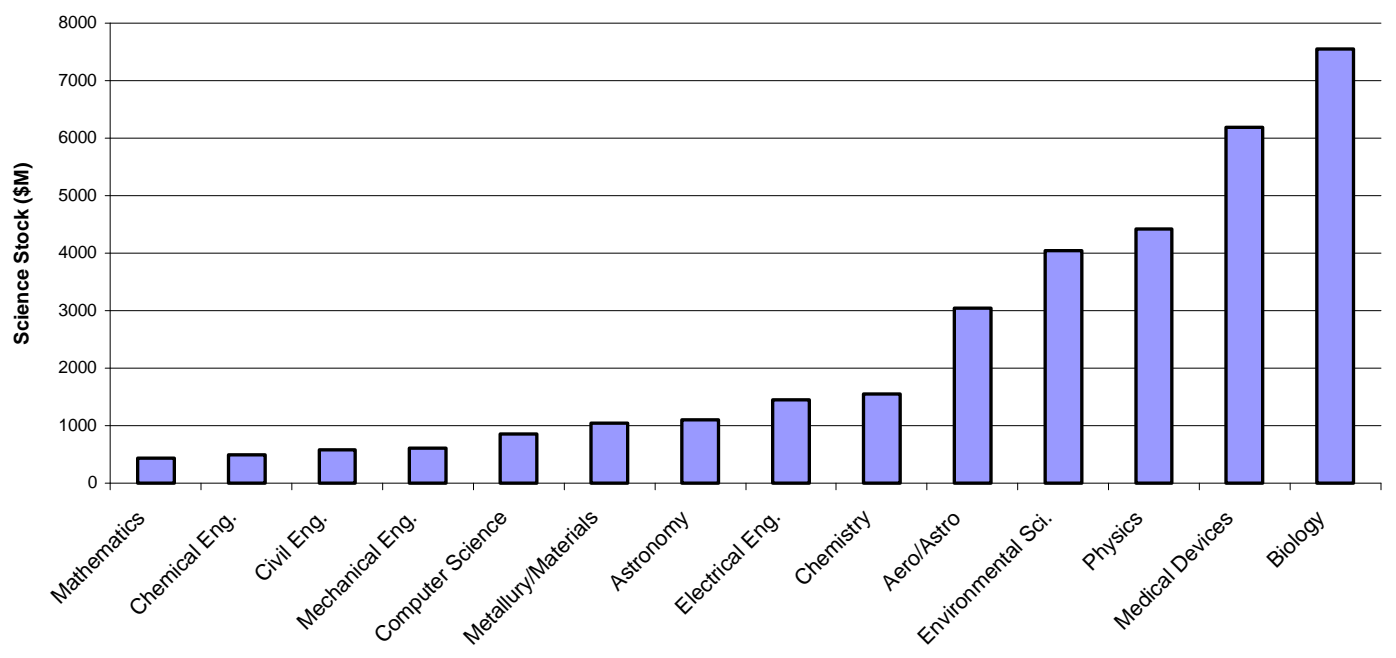

Academic Discipline 

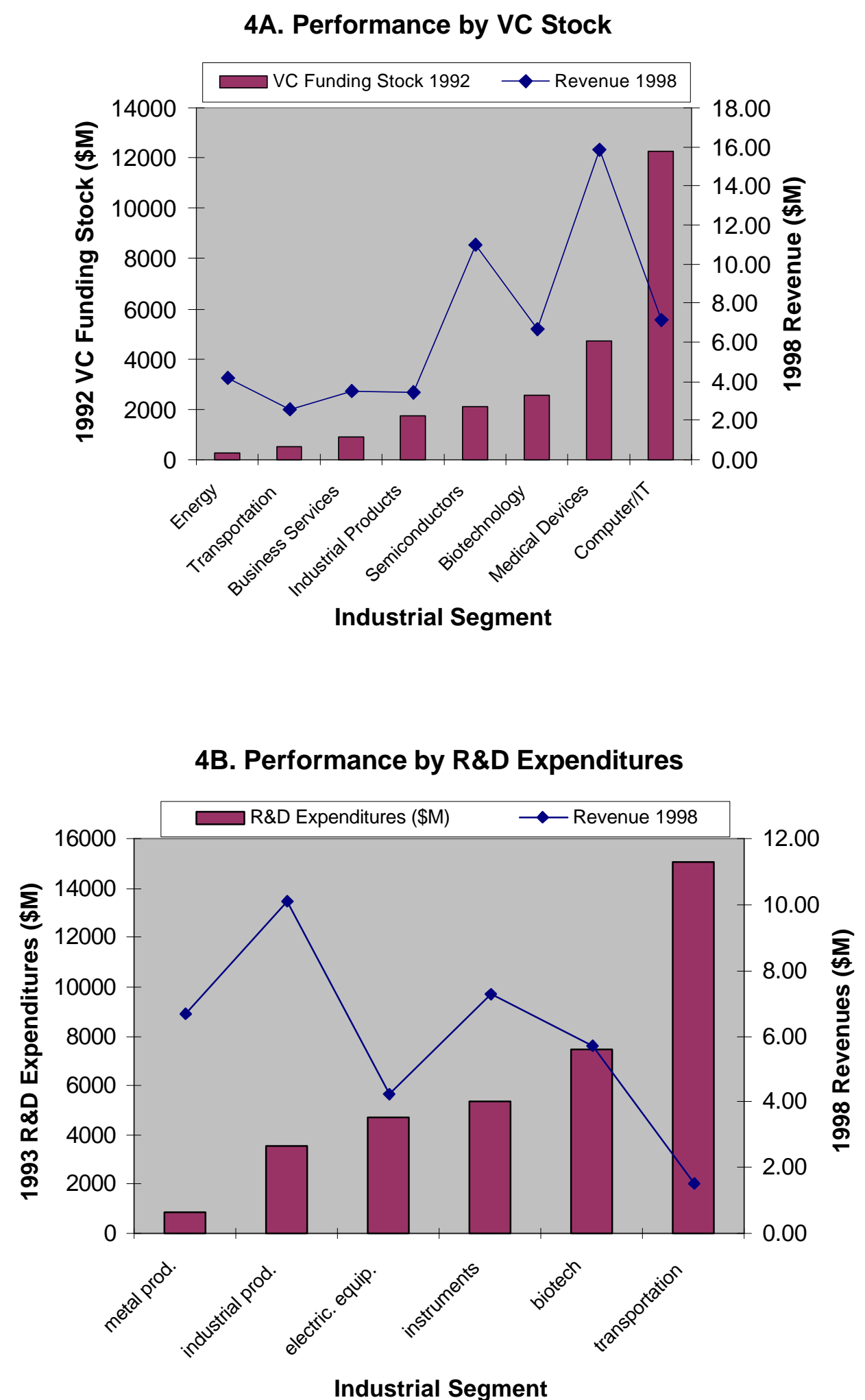

(Note: R\&D expenditures unreported for software \& business services) 
TABLE 1

VARIABLES* \& DEFINITIONS

\begin{tabular}{|c|c|c|}
\hline VARIABLE & DEFINITION & SOURCE \\
\hline \multicolumn{3}{|c|}{ PROJECT-LEVEL PERFORMANCE } \\
\hline REVENUE 98 & Total 1998 Revenues from Project & MIT Survey \\
\hline EMPOYMENT 98 & Total Employees in 1998 & MIT Survey \\
\hline \multicolumn{3}{|c|}{$\begin{array}{l}\text { PROJECT- AND FIRM-LEVEL CONTROL VARIABLES } \\
\end{array}$} \\
\hline PATENTS & Patents awarded since SBIR grant & USPTO \\
\hline COOPERATOR & $\begin{array}{l}\text { Dummy = } 1 \text { if Project Revenues include } \\
\text { licensing revenues, intellectual property sales, or } \\
\text { merger and acquisition, } 0 \text { else }\end{array}$ & MIT Survey \\
\hline UPGRADE & $\begin{array}{l}\text { Dummy = } 1 \text { if Project Technology has been } \\
\text { "substantially upgraded" since market } \\
\text { introduction or prototype, } 0 \text { else }\end{array}$ & MIT Survey \\
\hline TIME-TO-MARKET & $\begin{array}{l}\text { Months From Conception of Intial Project Idea } \\
\text { Until Product Market Introduction }\end{array}$ & MIT Survey \\
\hline MADE-TO-ORDER & $\begin{array}{l}\text { Dummy }=1 \text { if Firm Sells "Made-to-order" } \\
\text { Technologies, } 0 \text { else }\end{array}$ & MIT Survey \\
\hline SBIR AWARD SIZE & $\begin{array}{l}\text { SBIR Grant Awards Related to Project } \\
\text { Technology (both Phase I and Phase II included) }\end{array}$ & MIT Survey \\
\hline $\begin{array}{l}\text { BASELINE } \\
\text { EMPLOYEES }\end{array}$ & Total Employees in Firm at Start of Project & MIT Survey \\
\hline \multicolumn{3}{|c|}{$\begin{array}{c}\text { INDUSTRY OR SEGMENT-LEVEL VARIABLES } \\
\end{array}$} \\
\hline $\begin{array}{l}1992 \text { VC FUNDING } \\
\text { STOCK }\end{array}$ & $\begin{array}{l}\text { Total (undiscounted) stock of venture capital } \\
\text { investment in technology segment most closely } \\
\text { associated with project }\end{array}$ & $\begin{array}{l}\text { MIT Survey; Venture } \\
\text { One }\end{array}$ \\
\hline SCIENCE STOCK & $\begin{array}{l}\text { Total (discounted) stock of Federal expenditures } \\
\text { on scientific and engineering areas closely related } \\
\text { to project technology. See text for details. } \\
\text { NB: Stock is linear in all areas related to project }\end{array}$ & $\begin{array}{l}\text { MIT Survey; } \\
\text { NSF S\&E Indicators }\end{array}$ \\
\hline $\begin{array}{l}\text { SIC-LEVEL R\&D } \\
\text { EXPENDITURES }\end{array}$ & 1993 R\&D Expenditures in Project 3-digit SIC & $\begin{array}{l}\text { MIT Survey; NSF } \\
\text { S\&E Indicators }\end{array}$ \\
\hline SIC SIZE & 1993 Total SIC Sales & NSF S\&E Indicators \\
\hline \multicolumn{3}{|c|}{ APPROPRIABILITY VARIABLES } \\
\hline PATENT LIKERT & $\begin{array}{l}\text { 5-Point Managerial Likert Scale Rating of } \\
\text { Importance of Patents for Appropriating Returns }\end{array}$ & MIT Survey \\
\hline SECRECY LIKERT & $\begin{array}{l}\text { 5-Point Managerial Likert Scale Rating of } \\
\text { Importance of Secrecy for Appropriating Returns }\end{array}$ & MIT Survey \\
\hline $\begin{array}{l}\text { FIRST-MOVER } \\
\text { LIKERT }\end{array}$ & $\begin{array}{l}\text { 5-Point Managerial Likert Scale Rating of } \\
\text { Importance of being First to Market to } \\
\text { Appropriate Returns }\end{array}$ & MIT Survey \\
\hline \multicolumn{3}{|c|}{ COMPLEMENTARY ASSET VARIABLES } \\
\hline $\begin{array}{l}\text { MANUFACTURING } \\
\text { LIKERT }\end{array}$ & $\begin{array}{l}\text { 5-Point Managerial Likert Scale Rating of the } \\
\text { Importance of Control over Manufacturing }\end{array}$ & MIT Survey \\
\hline $\begin{array}{l}\text { DISTRIBUTION } \\
\text { LIKERT }\end{array}$ & $\begin{array}{l}\text { 5-Point Managerial Likert Scale Rating of the } \\
\text { Importance of Control over Distribution Channels }\end{array}$ & MIT Survey \\
\hline BRANDING LIKERT & $\begin{array}{l}\text { 5-Point Managerial Likert Scale Rating of the } \\
\text { Importance of Control over Branding Resources } \\
\text { in Earning Returns from the Project }\end{array}$ & MIT Survey \\
\hline SERVICING LIKERT & $\begin{array}{l}\text { 5-Point Managerial Likert Scale Rating of the } \\
\text { Importance of Control over Servicing Resources } \\
\text { in Earning Returns from the Project }\end{array}$ & MIT Survey \\
\hline
\end{tabular}

The natural logarithm of a variable, $\mathrm{X}$, will be denoted L X 
TABLE 2

MEANS \& STANDARD DEVIATIONS

\begin{tabular}{|l|c|c|}
\hline \multicolumn{1}{|c|}{ VARIABLE } & MEAN & STD. DEVIATION \\
\hline PROJECT-LEVEL PERFORMANCE & 6.453 & 13.145 \\
\hline REVENUE 98 & 87.784 & 97.973 \\
\hline EMPLOYMENT 98 & 8.928 & 13.104 \\
\hline PROJECT- AND FIRM-LEVEL CONTROL VARIABLES & 0.481 \\
\hline PATENTS & 0.351 & 0.371 \\
\hline COOPERATOR & 0.838 & 42.142 \\
\hline UPGRADE & 45.000 & 0.488 \\
\hline TIME-TO-MARKET & 0.622 & 1.458 \\
\hline MADE-TO-ORDER & 1.745 & 45.477 \\
\hline SBIR AWARD SIZE & 35.554 & 1380.537 \\
\hline BASELINE EMPLOYEES & 2361.752 & 4336.470 \\
\hline INDUSTRY OR SEGMENT-LEVEL VARIABLES & 7129.043 & 3014.836 \\
\hline 1992 VC FUNDING STOCK & 4564.783 & 1.313 \\
\hline SCIENCE STOCK & 62722.370 & 38679.860 \\
\hline SIC-LEVEL R\&D EXPENDITURES & & 1.229 \\
\hline SIC SIZE & 3.191 & 1.363 \\
\hline APPROPRIABILITY MECHANISM VARIABLES & 3.426 & 1.261 \\
\hline LIKERT PATENT & 3.723 & \\
\hline LIKERT SECRECY & 3.655 & \\
\hline LIKERT SPEED & 4.191 & \\
\hline LIKERT MANUFACTURING & 3.490 & \\
\hline LIKERT DISTRIBUTION & & \\
\hline LIKERT BRANDING & & \\
\hline LIKERT SERVICING & & \\
\hline
\end{tabular}


TABLE 3

PROJECT-LEVEL PERFORMANCE EQUATIONS (NO PROJECT-LEVEL CONTROLS)

\begin{tabular}{|c|c|c|c|c|c|}
\hline & \multicolumn{5}{|c|}{$\begin{array}{c}\text { Dependent Variable }=\text { L REVENUE } 98 \\
\text { N=71 observations, excludes "mills" }\end{array}$} \\
\hline & $\begin{array}{c}\mathbf{( 3 - 1 )} \\
\text { VC STOCK } \\
\text { only } \\
\end{array}$ & $\begin{array}{c}\text { (3-2) } \\
\text { SCI STOCK } \\
\text { only }\end{array}$ & $\begin{array}{c}\text { (3-3) } \\
\text { SIC R\&D } \\
\text { only }\end{array}$ & $\begin{array}{c}\text { (3-4) } \\
\text { SIC SIZE } \\
\text { only }\end{array}$ & $\begin{array}{c}\mathbf{( 3 - 5 )} \\
\text { Combination } \\
\text { Model }\end{array}$ \\
\hline $\begin{array}{l}\text { L } 1992 \text { VC FUNDING } \\
\text { STOCK }\end{array}$ & $\begin{array}{r}\mathbf{0 . 5 6 7} \\
(\mathbf{0 . 2 5 5 )} \\
\end{array}$ & & & & $\begin{array}{c}0.586 \\
(0.265) \\
\end{array}$ \\
\hline L SCIENCE STOCK & & $\begin{array}{c}0.383 \\
(0.267)\end{array}$ & & & $\begin{array}{c}0.281 \\
(0.271)\end{array}$ \\
\hline $\begin{array}{l}\text { L SIC-LEVEL R\&D } \\
\text { EXPENDITURES } \\
\end{array}$ & & & $\begin{array}{c}0.463 \\
(0.347) \\
\end{array}$ & & $\begin{array}{c}0.278 \\
(0.347) \\
\end{array}$ \\
\hline L SIC SIZE & & & & $\begin{array}{c}0.251 \\
(0.504)\end{array}$ & $\begin{array}{c}0.400 \\
(0.507)\end{array}$ \\
\hline Constant & $\begin{array}{l}-3.680 \\
(1.931)\end{array}$ & $\begin{array}{l}-2.703 \\
(2.308)\end{array}$ & $\begin{array}{l}-3.220 \\
(2.931)\end{array}$ & $\begin{array}{l}-2.112 \\
(5.605)\end{array}$ & $\begin{array}{r}-12.975 \\
(6.700)\end{array}$ \\
\hline R-Squared & 0.067 & 0.029 & 0.041 & 0.020 & 0.125 \\
\hline Adjusted R-Squared & 0.054 & 0.015 & 0.013 & -0.009 & 0.058 \\
\hline
\end{tabular}


TABLE 4

PROJECT-LEVEL PERFORMANCE AS A FUNCTION OF VC

\begin{tabular}{|c|c|c|c|c|}
\hline \multirow[t]{2}{*}{$\mathrm{N}=71$ observations } & \multicolumn{4}{|c|}{ Dependent Variable = L REVENUE 98} \\
\hline & $\begin{array}{c}\mathbf{( 4 - 1 )} \\
\text { Control for } \\
\text { Initial Firm } \\
\text { Size }\end{array}$ & $\begin{array}{c}\mathbf{( 4 - 2 )} \\
\text { (4-1) with Likert } \\
\text { Comp Asset } \\
\text { Controls }\end{array}$ & $\begin{array}{c}\mathbf{( 4 - 3 )} \\
(4-1) \text { with } \\
\text { Project-level } \\
\text { Controls }\end{array}$ & $\begin{array}{c}\mathbf{( 4 - 4 )} \\
\text { Combination } \\
\text { Model }\end{array}$ \\
\hline L 1992 VC FUNDING STOCK & $\begin{array}{c}\mathbf{0 . 5 3 7} \\
(\mathbf{0 . 2 6 5 )} \\
\end{array}$ & $\begin{array}{c}0.574 \\
(0.286) \\
\end{array}$ & $\begin{array}{c}\mathbf{0 . 5 5 0} \\
(\mathbf{0 . 2 5 8}) \\
\end{array}$ & $\begin{array}{c}\mathbf{0 . 5 1 0} \\
(\mathbf{0 . 7 4 7})\end{array}$ \\
\hline BASELINE EMPLOYEES & $\begin{array}{c}0.125 \\
(0.152) \\
\end{array}$ & $\begin{array}{c}0.096 \\
(0.175) \\
\end{array}$ & $\begin{array}{c}0.117 \\
(0.143) \\
\end{array}$ & $\begin{array}{c}0.135 \\
(0.169) \\
\end{array}$ \\
\hline LIKERT SERVICING & & $\begin{array}{l}-0.249 \\
(0.248)\end{array}$ & & $\begin{array}{l}-0.094 \\
(0.237) \\
\end{array}$ \\
\hline LIKERT DISTRIBUTION & & $\begin{array}{l}-0.150 \\
(0.262) \\
\end{array}$ & & $\begin{array}{c}0.028 \\
(0.237) \\
\end{array}$ \\
\hline LIKERT BRANDING & & $\begin{array}{c}0.039 \\
(0.260)\end{array}$ & & $\begin{array}{l}-0.141 \\
(0.258)\end{array}$ \\
\hline LIKERT MANUFACTURING & & $\begin{array}{c}0.446 \\
(0.352) \\
\end{array}$ & & $\begin{array}{c}0.266 \\
(0.344) \\
\end{array}$ \\
\hline LIKERT PATENT & & $\begin{array}{c}0.060 \\
(0.222)\end{array}$ & & $\begin{array}{c}0.182 \\
(0.215)\end{array}$ \\
\hline LIKERT SECRECY & & $\begin{array}{c}0.034 \\
(0.249) \\
\end{array}$ & & $\begin{array}{c}0.069 \\
(0.242) \\
\end{array}$ \\
\hline LIKERT SPEED & & $\begin{array}{c}0.348 \\
(0.299) \\
\end{array}$ & & $\begin{array}{c}0.200 \\
(0.287) \\
\end{array}$ \\
\hline PATENTS & & & $\begin{array}{c}\mathbf{0 . 0 3 7} \\
(\mathbf{0 . 0 1 5}) \\
\end{array}$ & $\begin{array}{c}\mathbf{0 . 0 3 0} \\
(\mathbf{0 . 0 1 7})\end{array}$ \\
\hline COOPERATOR & & & $\begin{array}{c}\mathbf{0 . 8 3 6} \\
(\mathbf{0 . 3 8 0}) \\
\end{array}$ & $\begin{array}{c}0.711 \\
(0.428) \\
\end{array}$ \\
\hline UPGRADE & & & $\begin{array}{c}1.007 \\
(0.499)\end{array}$ & $\begin{array}{c}0.961 \\
(0.551)\end{array}$ \\
\hline TIME-TO-MARKET & & & $\begin{array}{l}\mathbf{- 0 . 0 0 8} \\
(0.004) \\
\end{array}$ & $\begin{array}{l}-0.006 \\
(0.005) \\
\end{array}$ \\
\hline MADE-TO-ORDER & & & $\begin{array}{c}0.430 \\
(0.415) \\
\end{array}$ & $\begin{array}{c}0.387 \\
(0.485) \\
\end{array}$ \\
\hline L SBIR AWARD SIZE & & & $\begin{array}{l}-0.213 \\
(0.165)\end{array}$ & $\begin{array}{l}-0.286 \\
(0.176)\end{array}$ \\
\hline Constant & $\begin{array}{l}-\mathbf{- 3 . 7 6 3} \\
(\mathbf{1 . 9 5 3 )} \\
\end{array}$ & $\begin{array}{l}-6.221 \\
(2.830)\end{array}$ & $\begin{array}{l}-\mathbf{- 5 . 7 3 0} \\
(2.353)\end{array}$ & $\begin{array}{l}-7.717 \\
(3.439) \\
\end{array}$ \\
\hline R-Squared & 0.081 & 0.181 & 0.347 & 0.411 \\
\hline Adjusted R-Squared & 0.040 & 0.012 & 0.225 & 0.176 \\
\hline
\end{tabular}


TABLE 5

ALTERNATIVE INDUSTRY-LEVEL CORRELATES OF SBIR PERFORMANCE

\begin{tabular}{|c|c|c|c|}
\hline & \multicolumn{3}{|c|}{$\begin{array}{c}\text { Dependent Variable }=\text { L REVENUE } 98 \\
\text { N=71 observations, excludes "mills" }\end{array}$} \\
\hline & $\begin{array}{c}\mathbf{( 5 - 1 )} \\
\text { Science Stock } \\
\text { and Opportunity } \\
\text { Measures }\end{array}$ & $\begin{array}{c}\mathbf{( 5 - 2 )} \\
\text { Industry-level } \\
\text { Expenditures / } \\
\text { Opportunity } \\
\text { Measures }\end{array}$ & $\begin{array}{c}\mathbf{( 5 - 3 )} \\
\text { Combination } \\
\text { Model }\end{array}$ \\
\hline L SCIENCE STOCK & $\begin{array}{c}0.603 \\
(0.279)\end{array}$ & & $\begin{array}{c}0.655 \\
(0.295)\end{array}$ \\
\hline $\begin{array}{l}\text { L SIC-LEVEL R\&D } \\
\text { EXPENDITURES }\end{array}$ & & $\begin{array}{c}0.178 \\
(0.360)\end{array}$ & $\begin{array}{l}-0.079 \\
(0.348)\end{array}$ \\
\hline L 1992 VC FUNDING STOCK & & & $\begin{array}{c}0.613 \\
(0.278) \\
\end{array}$ \\
\hline FIRM-LEVEL CONTROLS & YES & YES & YES \\
\hline PROJECT-LEVEL CONTROLS & YES & YES & YES \\
\hline COMPL. ASSET CONTROLS & YES & YES & YES \\
\hline $\begin{array}{l}\text { APPROPRIABILITY REGIME } \\
\text { CONTROLS }\end{array}$ & YES & YES & YES \\
\hline Constant & $\begin{array}{l}-7.605 \\
(3.245)\end{array}$ & $\begin{array}{l}-4.493 \\
(3.746)\end{array}$ & $\begin{array}{r}-12.656 \\
(4.445)\end{array}$ \\
\hline R-Squared & 0.420 & 0.374 & 0.474 \\
\hline Adjusted R-Squared & 0.188 & 0.106 & 0.217 \\
\hline
\end{tabular}


TABLE 6

FIRM EMPLOYMENT EQUATIONS

(NO PROJECT-LEVEL CONTROLS)

\begin{tabular}{|c|c|c|c|c|c|}
\hline & \multicolumn{5}{|c|}{$\begin{array}{c}\text { Dependent Variable = L EMPLOYMENT } 98 \\
\text { N=71 observations, excludes "mills" }\end{array}$} \\
\hline & $\begin{array}{c}\mathbf{( 6 - 1 )} \\
\text { VC } \\
\text { STOCK } \\
\text { only }\end{array}$ & $\begin{array}{c}(\mathbf{6 - 2}) \\
\text { SCI } \\
\text { STOCK } \\
\text { only }\end{array}$ & $\begin{array}{c}\text { (6-3) } \\
\text { SIC R\&D } \\
\text { only }\end{array}$ & $\begin{array}{c}\text { (6-4) } \\
\text { SIC SIZE } \\
\text { only }\end{array}$ & $\begin{array}{c}(\mathbf{6 - 5}) \\
\text { Combination } \\
\text { Model }\end{array}$ \\
\hline $\begin{array}{l}\text { BASELINE } \\
\text { EMPLOYMENT }\end{array}$ & $\begin{array}{c}\mathbf{0 . 3 2 4} \\
(\mathbf{0 . 0 1 0})\end{array}$ & $\begin{array}{c}\mathbf{0 . 3 7 7} \\
(\mathbf{0 . 0 1 0})\end{array}$ & $\begin{array}{c}0.364 \\
(0.102)\end{array}$ & $\begin{array}{c}0.373 \\
(\mathbf{0 . 1 0 0})\end{array}$ & $\begin{array}{c}0.339 \\
(\mathbf{0 . 1 0 3})\end{array}$ \\
\hline $\begin{array}{l}\text { L } 1992 \text { VC } \\
\text { FUNDING STOCK }\end{array}$ & $\begin{array}{c}0.334 \\
(\mathbf{0 . 1 7 4})\end{array}$ & & & & $\begin{array}{c}0.380 \\
(\mathbf{0 . 1 8 2})\end{array}$ \\
\hline L SCIENCE STOCK & & $\begin{array}{c}0.156 \\
(0.178)\end{array}$ & & & $\begin{array}{c}0.128 \\
(0.183)\end{array}$ \\
\hline $\begin{array}{l}\text { L SIC-LEVEL R\&D } \\
\text { EXPENDITURES }\end{array}$ & & & $\begin{array}{c}0.047 \\
(0.235)\end{array}$ & & $\begin{array}{l}-0.065 \\
(0.236)\end{array}$ \\
\hline L SIC SIZE & & & & $\begin{array}{c}0.306 \\
(0.338)\end{array}$ & $\begin{array}{c}0.421 \\
(0.344)\end{array}$ \\
\hline Constant & $\begin{array}{c}0.377 \\
(1.279)\end{array}$ & $\begin{array}{c}1.394 \\
(1.591)\end{array}$ & $\begin{array}{c}2.379 \\
(1.965)\end{array}$ & $\begin{array}{l}-0.661 \\
(3.792)\end{array}$ & $\begin{array}{l}-5.252 \\
(4.523)\end{array}$ \\
\hline R-Squared & 0.217 & 0.184 & 0.175 & 0.184 & 0.244 \\
\hline Adjusted R-Squared & 0.182 & 0.147 & 0.125 & 0.135 & 0.160 \\
\hline
\end{tabular}




\section{APPENDIX C}

TABLE C-1

EQUITY \& GEOGRAPHY CONTROLS

\begin{tabular}{|c|c|c|c|}
\hline & \multicolumn{3}{|c|}{$\begin{array}{c}\text { Dependent Variable = L REVENUE } 98 \\
\text { N=71 observations, excludes "mills" }\end{array}$} \\
\hline & \begin{tabular}{|c|}
$\mathbf{( A 1 - 1 )}$ \\
Control for VC \\
EQUITY \\
SHARE
\end{tabular} & $\begin{array}{c}\text { (A1-2) } \\
\text { Control for } \\
\text { Management } \\
\text { and Employee } \\
\text { Equity Share }\end{array}$ & $\begin{array}{c}\text { (A1-3) } \\
\text { Exploring } \\
\text { Geographic } \\
\text { Effects }\end{array}$ \\
\hline L SCIENCE STOCK & $\begin{array}{c}0.532 \\
(0.328)\end{array}$ & $\begin{array}{c}0.615 \\
(0.315)\end{array}$ & $\begin{array}{c}\mathbf{0 . 6 8 9} \\
(\mathbf{0 . 3 0 4})\end{array}$ \\
\hline $\begin{array}{l}\text { L SIC-LEVEL R\&D } \\
\text { EXPENDITURES }\end{array}$ & $\begin{array}{l}-0.090 \\
(0.352)\end{array}$ & $\begin{array}{l}-0.086 \\
(0.347)\end{array}$ & $\begin{array}{c}0.004 \\
(0.369)\end{array}$ \\
\hline L 1992 VC FUNDING STOCK & $\begin{array}{c}\mathbf{0 . 6 0 6} \\
(\mathbf{0 . 2 8 3}) \\
\end{array}$ & $\begin{array}{c}0.512 \\
(0.285) \\
\end{array}$ & $\begin{array}{c}0.636 \\
(0.284) \\
\end{array}$ \\
\hline VC EQUITY SHARE & $\begin{array}{l}-0.012 \\
(0.014)\end{array}$ & & \\
\hline INSIDER EQUITY SHARE & & $\begin{array}{l}-0.010 \\
(0.007)\end{array}$ & \\
\hline LOCATED IN NY & & & $\begin{array}{c}1.560 \\
(1.035)\end{array}$ \\
\hline LOCATED IN CA & & & $\begin{array}{c}0.251 \\
(0.502)\end{array}$ \\
\hline LOCATED IN MA & & & $\begin{array}{c}0.050 \\
(0.653)\end{array}$ \\
\hline FIRM-LEVEL CONTROLS & YES & YES & YES \\
\hline PROJECT-LEVEL CONTROLS & YES & YES & YES \\
\hline COMPL. ASSET CONTROLS & YES & YES & YES \\
\hline $\begin{array}{l}\text { APPROPRIABILITY REGIME } \\
\text { CONTROLS }\end{array}$ & YES & YES & YES \\
\hline Constant & $\begin{array}{c}-11.111 \\
(5.254)\end{array}$ & $\begin{array}{r}-10.529 \\
(5.198)\end{array}$ & $\begin{array}{r}-13.022 \\
(4.476)\end{array}$ \\
\hline R-Squared & 0.486 & 0.501 & 0.502 \\
\hline Adjusted R-Squared & 0.200 & 0.224 & 0.208 \\
\hline
\end{tabular}


TABLE C-2

VARYING THE SAMPLE \& THE VC MEASURE

\begin{tabular}{|c|c|c|c|}
\hline & \multicolumn{3}{|c|}{ Dependent Variable = L REVENUE 98} \\
\hline & $\begin{array}{l}\text { (A2-1) } \\
\text { Excludes } \\
\text { "mills" and } \\
\text { imposes } \\
\text { product } \\
\text { revenue } \\
\text { threshold for } \\
\text { inclusion in } \\
\text { the sample } \\
\mathrm{N}=43\end{array}$ & $\begin{array}{l}\text { (A2-2) } \\
\text { Includes } \\
\text { "mills" in the } \\
\text { sample } \\
\mathrm{N}=74\end{array}$ & $\begin{array}{c}\text { (A2-3) } \\
\text { Excludes } \\
\text { "mills"and } \\
\text { imposes product } \\
\text { revenue threshold } \\
\text { for inclusion in the } \\
\text { sample } \\
\\
\mathrm{N}=71\end{array}$ \\
\hline L SCIENCE STOCK & $\begin{array}{c}0.739 \\
(0.502)\end{array}$ & $\begin{array}{c}\mathbf{0 . 6 7 0} \\
(\mathbf{0 . 2 8 8})\end{array}$ & $\begin{array}{c}0.626 \\
(0.299)\end{array}$ \\
\hline $\begin{array}{l}\text { L SIC-LEVEL R\&D } \\
\text { EXPENDITURES }\end{array}$ & $\begin{array}{l}-0.053 \\
(0.504)\end{array}$ & $\begin{array}{l}-0.010 \\
(0.349)\end{array}$ & $\begin{array}{l}-0.084 \\
(0.357)\end{array}$ \\
\hline L 1992 VC FUNDING STOCK & $\begin{array}{c}1.242 \\
(0.520) \\
\end{array}$ & $\begin{array}{c}0.567 \\
(0.268) \\
\end{array}$ & $\begin{array}{c}0.440 \\
(0.253) \\
\end{array}$ \\
\hline BASELINE EMPLOYEES & $\begin{array}{c}0.028 \\
(0.308)\end{array}$ & $\begin{array}{c}0.228 \\
(0.170)\end{array}$ & $\begin{array}{c}0.244 \\
(0.176)\end{array}$ \\
\hline PATENTS & $\begin{array}{c}0.021 \\
(0.021)\end{array}$ & $\begin{array}{c}\mathbf{0 . 0 3 0} \\
(\mathbf{0 . 0 1 7})\end{array}$ & $\begin{array}{c}0.031 \\
(\mathbf{0 . 0 1 8})\end{array}$ \\
\hline PROJECT-LEVEL CONTROLS & YES & YES & YES \\
\hline COMPL. ASSET CONTROLS & YES & YES & YES \\
\hline $\begin{array}{l}\text { APPROPRIABILITY REGIME } \\
\text { CONTROLS }\end{array}$ & YES & YES & YES \\
\hline Constant & $\begin{array}{r}-16.940 \\
(7.144) \\
\end{array}$ & $\begin{array}{r}-13.168 \\
(4.446)\end{array}$ & $\begin{array}{r}-10.159 \\
(4.161)\end{array}$ \\
\hline R-Squared & 0.546 & 0.463 & 0.455 \\
\hline Adjusted R-Squared & 0.003 & 0.216 & 0.189 \\
\hline
\end{tabular}




\section{Appendix A: Sources of Capital Market Imperfections}

In Section III, we considered the effect of a capital subsidy. We argued that a capital subsidy effectively eliminates problems caused by capital market imperfections or at least equalizes them for grant recipients across industries. Suppose, as we will do through this appendix, that $c(F, \theta)=F+\theta$. We consider in more detail the reasons why $\theta>0$ by looking at three alternative models based on moral hazard, adverse selection and expropriation. In each the capital market imperfection will arise when a particular parameter, $\phi$, is positive. We will demonstrate that $\theta=0$ whenever the parameter $\phi$ is zero. Finally, in what follows, we omit the industry subscript, $i$, from notation.

\section{(a) Moral Hazard}

Suppose that the RU employs effort in innovative activity and that this can influence the likelihood of generating a successful innovation. We assume that this effort has a contractible and a non-contractible component. Using only contractible effort, the probability of generating a successful innovation is $p_{L}$. We normalize the cost of this effort to 0 . However, by expending non-contractible effort for a marginal cost of 1 , the RU can raise this innovation probability to $p_{H}$ $>p_{L}$.

We make two simplifying assumptions. First, we assume that research and capital provision to the RU is socially desirable for some projects, i.e., $p_{H} \bar{V}>F+1$. Second, we assume that there exists $\bar{F}$ beyond which it is never worthwhile providing capital to the RU if it is not expected to expend a high level of effort in innovative activity, i.e., $p_{L} v(\bar{V}, \gamma)=\bar{F}$. The former assumption raises the possibility that some socially desirable projects may go unfunded because of a lack of appropriability. The latter assumption, however, means that the VC may not fund some privately profitable projects. This is essentially because of a capital market imperfection that dilutes the role of VC-equity when RU effort is non-contractible.

Turning to the determinants of VC funding let $\alpha$ denote the level of equity the RU retains in its own firm. This level of equity (and any capital forthcoming from the VC) is determined prior to the RU engaging in any innovative activity. The minimum level of equity the RU can have and still expend a high level of effort ex post is given by the $\underline{\alpha}$ that just satisfies the RU's incentive constraint:

$$
p_{H} \underline{\alpha} v-1 \geq p_{L} v \Rightarrow \underline{\alpha} \geq \frac{1}{v\left(p_{H}-p_{L}\right)}
$$

Given the competitive nature of VC capital markets, VC capital will be forthcoming for the project so long as it is still profitable at this minimum RU-equity level.

$$
p_{H}(1-\underline{\alpha}) v \geq F
$$


Substituting for $\underline{\alpha}$, we can re-write the participation constraint for the VC as:

$$
p_{H} v-1 \geq F+\phi
$$

where $\phi=p_{L} /\left(p_{H}-p_{L}\right)$. Notice that, in this model, $\theta=\phi$; meaning that the private cost of capital exceeds the social cost of capital whenever, $\phi>0$.

\section{(b) Adverse Selection}

In the previous model, the capital market imperfection arose because of the detrimental effect of $\mathrm{VC}$ equity on the incentives of the RU to expend non-contractible effort in innovative activity. Here we consider an alternative model where the probability of a successful innovation depends on the RU's 'type' that is private information to the RU. We suppose that there are two types of RU's. RU's with high ability generate a successful innovation with probability $p_{H}$ while for those with lower ability this probability is reduced to $p_{L}$. There is no non-contractible RU effort. It is assumed that a given RU is a high type with probability 1- $\phi$ and this is commonly known. The potential value of the project, $v$, is, however, known. Finally, we maintain the assumption of the previous sub-section that $p_{H} \bar{V}>F$ and $p_{L} v(\bar{V}, \gamma)<F$.

Recall that the VC market is competitive, so RUs can demand the maximum level of equity for a given project, $v$. However, as they cannot signal their type, the maximum RU equity that either the high or low type can demand is:

$$
\begin{aligned}
& \left((1-\phi) p_{H}+\phi p_{L}\right)(1-\alpha) v=F \\
& \Rightarrow \alpha=1-\frac{F}{\left((1-\phi) p_{H}+\phi p_{L}\right) v}
\end{aligned}
$$

This means that the lowest value project that can be funded in an industry is determined by the $v$ that results in $\alpha=0$; i.e., $v=\frac{F}{(1-\phi) p_{H}+\phi p_{L}}$. Notice that this is increasing in $\phi$ implying that the inability of VCs to distinguish good RUs from bad results in a high threshold for funding and, consequently, a lower level of VC funding in the industry. Thus, for this model, $\theta=\frac{\phi\left(p_{H}+p_{L}\right)}{(1-\phi) p_{H}+\phi p_{L}}$. This equals 0 if $\phi=0$.

\section{(c) Expropriation}

Our final model of capital market perfections is based on the potential for expropriation of ideas by a VC. When an RU approaches a given $\mathrm{VC}$ for funding they must reveal their potential idea. In some situations, an RU will provide inputs that are required for that idea to become commercially viable. In other situations, however, the RU does not add any value in this sense. If property rights over the idea are weak (as they may be prior to any patents or copyright), then a VC may expropriate the idea and refuse to let the RU share in any returns. 
This is a fundamental difficulty in any trade in ideas (Arrow, 1962; and Anton and Yao, 1994) and it constrains RU appropriability in at every stage of innovation.

We suppose that, provided a unit of capital is expended, the idea becomes commercializable with probability, $p$, and the potential return, $v$, is common knowledge. However, it is possible that the VC simply expropriate the full private return $v$ if approached by the RU. Anticipating this, the RU may not develop the idea of approach the RU (although here there is no incentive for the RU not to bring the idea to a $\mathrm{VC}^{22}$ ). Nonetheless, a capital constrained RU may have some alternative means of raising capital. This is certainly the case here given our assumption of a competitive VC market. If one VC were to expropriate the idea, the idea may be financed by another VC.

To see this, recall that product market appropriation $(\gamma)$ depends in part on the degree of competition an innovation faces. That is, are there products that are close substitutes? If the RU were to turn to another $\mathrm{VC}$, it may be able to reduce product market appropriation to $(1-\phi) \gamma$; even though it would not receive any ex post rents itself in this eventuality. Fearing the RU's competitive threat from disclosure to others, the initial VC may not expropriate the RU; instead giving the RU some equity in the venture.

This means that RU-equity will be determined through a bilateral negotiation between themselves and the first VC they approach. This equity is, therefore, not determined competitively but through a bilateral monopoly. Essentially, both the RU and VC can use the threat of disclosure to others or expropriation to bind themselves to reach agreement.

Following disclosure of the idea to the VC, the two parties negotiate over the equity level given to the RU. Assuming Nash bargaining with equal bargaining power this yields:

$$
\begin{aligned}
& p(1-\alpha) v-F-(p(1-\phi) v-F)=p \alpha v \\
& \Rightarrow \alpha=\frac{1}{2} \phi
\end{aligned}
$$

A project with social value, $V$, will be funded if and only if the VC's participation constraints (expecting this level of equity) are satisfied. This participation constraint is $p v \geq \frac{2}{2-\phi} F$. Consequently, the private cost of capital for this model is given by $\theta=\frac{\phi}{2-\phi} F$ and it clearly exceeds 0 for $\phi \in(0,2]$.

\footnotetext{
${ }^{22}$ One could imagine that the RU has some sunk expenditures prior to bringing an idea to a VC that would be lost in the face of expropriation. This could be added to the model here but it would not alter the basic insight below about the high private cost of capital; it would merely complicated the cost of capital function.
} 


\title{
APPENDIX C: MIT SLOAN SCHOOL COMMERCIALIZATION STRATEGIES SURVEY
}

\author{
Principal Investigators: Professor Scott Stern, MIT Sloan School \& NBER \\ and Professor Joshua Gans, University of Melbourne \\ Researcher: David Hsu, MIT.
}

The goal of this project is to evaluate how companies commercialize innovative new technologies. We are exploring different commercialization strategies and how success at a technical level affects firm strategy.

Enclosed is a survey, which asks you to describe the circumstances surrounding a specific innovative project or initiative. We would like to focus on your firm's involvement in its main business area. Within that frame, please choose a research and/or development project which is internally perceived as an important source of value for your firm. We would like you to choose a project which provided direct financial returns for the firm, through direct sales, licensing agreements, or in strengthening the bargaining position of the firm.

Once the project is chosen, the survey is divided into two parts:

- $\quad$ General background of your company

- Commercialization history of the innovation

Participation in this study is entirely voluntary, and you can decline to answer any questions or decline further participation at any time. The survey should take no more than 25 minutes to complete. Responses will be kept both confidential and anonymous. Please return this survey and direct inquiries to:

Professor Scott Stern

MIT Sloan School

E52-554

Cambridge, MA 02142

TEL: 617-253-5219

FAX: 617-253-2660

e-mail: sstern@mit.edu

Thank you for your participation! 


\section{MIT SLOAN SCHOOL \\ COMMERCIALIZATION STRATEGIES SURVEY}

Name of Firm:

Year Founded: 19

\section{Part I: Background Information}

A. Employee Information

\# of Employees: At the start of chosen project Currently

What share of employees hold as their highest degree:

$\mathrm{BA} / \mathrm{BS}$

$\%$
Ph.D. $\%$

What share of employees have backgrounds in:

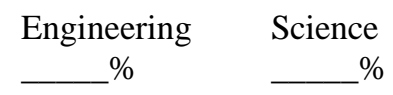

Is there a management track for technically trained employees?

Are senior managers promoted from within the firm?

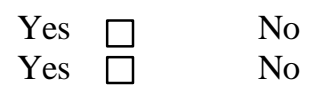

Please rank the relative importance of the following factors in determining the promotion of scientists \& engineers (with $1=$ most important $-4=$ least important):

External research reputation

Demonstrated contribution to R\&D teams

Demonstrated contribution to cross-functional teams

Management ability

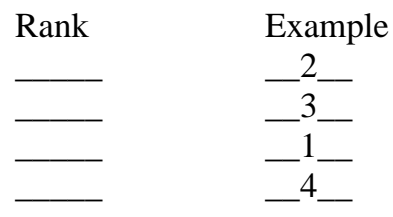

B. Financial Information

What is the percentage of corporate ownership held by the following groups:

Public Top Mgt. Employees

Venture
Capitalists
$\%$

"Angel" Investors

Other: $\%$

$\% \quad \%$
$\%$ $\%$ $\%$

What mechanisms are used to fund new technology development or R\&D projects (check all that apply):

$\square$ Internal Cash

$\square$ Partnering w/ Suppliers $\square$ Contract Research $\square$ Equity

What is the percentage of gross revenues devoted towards:

$\mathrm{R} \& \mathrm{D}$

$\%$
New Product

Development
Marketing

$\%$
$\%$ 
Total sales for your company: When the project was initiated In 1998

$\$$

$\$$

C. Organizational Governance \& Structure

\# of Directors:

What share of directors are:

\begin{tabular}{rrr} 
Internal & $\begin{array}{c}\text { External } \\
\%\end{array}$ & VC-Appointed \\
\hline
\end{tabular}

Which characteristics in the first column apply to the following executives?

$\begin{array}{lcc} & \text { CEO } & \text { Presiden } \\ \text { Firm founder } & \square & \square \\ \text { Promoted from within } & \square & \square \\ \text { Hired externally } & \square & \square \\ \text { Has run other companies } & \square & \square\end{array}$

R\&D or Technology Director

How many distinct products does your firm develop?

How many alliances has your company entered into with another firm?

What were the nature of these alliances? $\square$ Research \& Development $\square$ Manufacturing $\square$ Sales/Marketing

$\square$ Product Development $\square$ Distribution

Has your firm entered into any licensing deals? $\quad \square$ Yes: licensed-out $\quad \square$ Yes: licensed-in $\square$ No If your firm has licensed-out, what were the total licensing revenues? $1998 \$ \_$Total \$

What were the terms? $\square$ Exclusive $\square$ Non-Exclusive

Who were the licensees? (mark all that apply) $\square$ Product Market Incumbents

Product Market Entrants

$\square$ Government Agencies $\square$ Non-market agents (e.g., universities)

\section{Part II: Commercialization History of Chosen Project}

Name of technology/product:

Brief description of the technology:

Was this technology originated from research and development performed at your firm? $\square$ Yes $\square$ No

If the technology did not originate from your firm, where did it come from? $\square$ Licensed from university $\quad \square$ Licensed from corporate lab

$\square$ Licensed from parent firm $\square$ Other: 
Number of patents issued directly related to this technology:

Number of patents issued to your organization since founding:

Please check the terms which best describe this technology:
$\square$ Assembled
$\square$ Non-Assembled

Please check the terms which best describe the innovation (check all that apply):

$\square$ Product Innovation

$\square$ Process Innovation

$\square$ Novel components within a relatively standard system

$\square$ Novel overall system

What year was the product's first commercial introduction?

19

Time from conception of technology to first prototype:

months

Time from prototype to first sale:

months

Financing history of this project:

Year Source

Amount

For this project, what activities did the following actors facilitate?

Locating key personnel such as

$\begin{array}{llcc}\text { venture } & \text { angel } & \text { other } & \text { legal } \\ \text { capitalist } & \text { investor } & \text { board members } & \text { counsel }\end{array}$
managers and technologists

Locating sources of additional capital

Gaining access to critical technologies

Increasing the firm's focus on a small number of projects, technologies, or markets

Locating and arranging introductions with potential alliance partners

Participating in discussions over licensing and commericalization strategies

Other (specify)

What are the sources of revenue (on a percentage basis) associated with this technology?

Sales $\%$
Licensing Revenue $\%$
Intellectual Property

Asset Sale

$\%$ 
Share of revenues of this project from government contracts:

What is the number of distinct customers for this project?:
$\square<10$
$\square 10-100$
$101-500$
$\square>500$

Form of sales (check all that apply):

$\square$ made to order $\quad \square$ mass produced $\quad \square$ mass customized

Total sales of the product

Sales attributable to this product in 1998 ?

Sales attributable to this product since the inception of this project?

$\$$

$\$$

Has your firm been acquired since the development of this technology? $\quad \square$ Yes $\quad \square$ No

If so, by whom?

Does the new firm (after the merger) have more than 500 employees? $\quad \square$ Yes $\quad \square$ No

Why did your company decide to undergo an acquisition?

Has the product been substantially modified/upgraded since development of the first working prototype?

$\square$ No $\quad \square$ Yes; If yes, please describe the modifications:

If this technology resulted in licensing revenues,

What was the first year in which the technology was licensed?

What was the licensing revenue? 1998 \$

What were the terms?

$\square$ Exclusive

Were other technologies bundled in the license?

$\square$ Yes

Total $\stackrel{19}{\$}$
$\square$ Non-Exclusive
$\square$ No

Who were the licensees? (mark all that apply) $\square$ Product Market Incumbents

Product Market Entrants

$\square$ Government Agencies

$\square$ Non-market agents (e.g., universities)

Why did your company decide to license-out this technology? 
Please rate the importance of the strategic goals this technology enabled for your company:

Attraction of venture capital or outside funding

\begin{tabular}{cccccc} 
LOW & \multicolumn{5}{c}{ HIGH } \\
N/A & 1 & 2 & 3 & 4 & 5 \\
N/A & 1 & 2 & 3 & 4 & 5 \\
N/A & 1 & 2 & 3 & 4 & 5 \\
N/A & 1 & 2 & 3 & 4 & 5 \\
N/A & 1 & 2 & 3 & 4 & 5
\end{tabular}

Who were the key personnel involved in formulating the commercialization strategy for this product?

$\square$ CEO $\square$ Technology/R\&D Manager $\quad \square$ Marketing and sales manager

You mentioned before that the project's first prototype was developed around 19_. From that time onwards, your success with this technology likely depended, at least in part, on your control of resources which were not directly linked to the technology itself and on your ability to protect the innovation from imitation by others through intellectual property protection. Let's first consider how important your firm's control over resources has been in earning profits from this innovation. For each factor below, rate the importance over access and control of this resource on a scale from 1 to 5 . A rating of " 5 " would mean that control over this resource was critical for earning profits from this innovation while a " 1 " would imply that control over this resource was not important at all.

The capability to manufacture the product

The principal distribution channels for the technology

The association of the technology with a well-known

$\begin{array}{lllll}\text { LOW } & & & & \text { HIGH } \\ 1 & 2 & 3 & 4 & 5 \\ 1 & 2 & 3 & 4 & 5 \\ 1 & 2 & 3 & 4 & 5 \\ & & & & \\ 1 & 2 & 3 & 4 & 5\end{array}$

the product through marketing or advertising

Control over the sales force and servicing resources

for this product or technology

Now, let's turn to your ability to protect the innovation from imitation by others through intellectual property protection. For each factor below, rate the effectiveness of each factor in deterring imitation of the technology on a scale from 1 to 5 . A rating of " 5 " would mean that this factor was very effective in deterring imitation of the technology while a rating of " 1 " implies that this factor had no impact on your ability to deter imitation.

Trade secrecy

Patents \& copyright protection

Active patent or copyright litigation

$\begin{array}{lllll}\text { LOW } & & & & \text { HIGH } \\ 1 & 2 & 3 & 4 & 5 \\ 1 & 2 & 3 & 4 & 5 \\ 1 & 2 & 3 & 4 & 5\end{array}$

What activities were involved in the process of commercializing this technology and deciding how to earn returns from the innovation?

$\square$ Took an outside offer for purchasing the rights to the technology

$\square$ Shopped the technology around but was unable to sell a license to the technology

$\square$ Shopped the technology around and sold a license to the technology

$\square$ Did not shop the technology: Always had the intention of competing with the technology

$\square$ Other: 


\section{References}

Adams, J. (1990), "Fundamental Stocks of Knowledge and Productivity Growth," Journal of Political Economy, 98 (4), pp. 673-702.

Aghion, P. and J. Tirole (1994), "The Management of Innovation," Quarterly Journal of Economics, 109 (4), pp.1185-1210.

Anand, B. and A. Galetovic (1999), "Weak Property Rights and Hold-up in R\&D," Working Paper, No.99-007, Harvard Business School.

Anton, J.J. and D.A. Yao (1994), "Expropriation and Inventions: Appropriable Rents in the Absence of Property Rights," American Economic Review, 84 (1), pp.190-209.

Arrow, K.J. (1962), "Economic Welfare and the Allocation of Resources for Invention," in The Rate and Direction of Inventive Activity, Princeton University Press: Princeton, pp.609625.

Bresnahan, T., M. Trajtenberg and S. Stern (1997), "Market Segmentation and the Sources of Rents from Innovation: Personal Computers in the Late 1980s," Rand Journal of Economics, 28 (0), pp.S17-44.

Cockburn, I. and Z. Griliches (1988), "Industry Effects and Appropriability Measures in the Stock Market's Valuation of R\&D and Patents," American Economic Review, 78 (2), pp.419-23.

Cockburn, I. and R. Henderson (1994), "Racing to Invest? The Dynamics of Competition in Ethical Drug Discovery," Journal of Economics and Management Strategy, 3 (3), pp.481-519.

Cohen, L. and R. Noll (1993), The Technology Pork Barrel, Brooking Institution: Washington (DC).

Cohen, W. and D. Levinthal (1990), "Absorptive Capacity: A New Perspective on Learning and Innovation," Administrative Science Quarterly, 35(1), pp. 128-152.

Cohen, W., R.R. Nelson and J.P. Walsh (2000), "Protecting Their Intellectual Assets: Appropriability Conditions and Why U.S. Manufacturing Firms Patent (or Not)," Working Paper, No.7552, NBER.

Crepon, B., E. Duguet and J. Mairesse (1998). "Research, Innovation and Productivity: An Econometric Analysis at the Firm Level," Economics of Innovation \& New Technology, 7 (2), pp.115-58.

David, P. and B.H. Hall (2000), "Heart of Darkness: Modeling Public-Private Funding Interactions Inside the R\&D Black Box," Working Paper, No. 7538, NBER. 
Gans, J.S., D. Hsu and S. Stern (2000), "When Does Start-Up Innovation Spur the Gale of Creative Destruction?" mimeo., MIT.

Gans, J.S. and S. Stern (2000), "Incumbency and R\&D Incentives: Licensing the Gale of Creative Destruction," Journal of Economics and Management Strategy, (forthcoming).

General Accounting Office (1995), Federal Research: Interim Report on the Small Business Innovation Research Program.

Geroski, P.A. (1994). Market Structure, Corporate Performance and Innovative Activity.. Oxford University Press.

Geroski, P., S. Machin and J. Van Reenen (1993), “The Profitability of Innovating Firms,” Rand Journal of Economics, 24 (2), pp.198-211.

Gilbert, R. and D. Newbery (1982), "Preemptive Patenting and the Persistence of Monopoly," American Economic Review, 72 (3), pp.514-526.

Gompers, P.A. and J. Lerner (1998), "What Drives Venture Capital Fundraising?" Brookings Papers on Economic Activity: Microeconomics, pp.149-192.

Griliches, Z (1986), "Productivity, R\&D, and the Basic Research at the Firm Level in the 1970's" American Economic Review, 76 (1), pp.141-54.

Griliches, Z. (1998), R\&D and Productivity, University of Chicago Press: Chicago.

Griliches, Z., B.H. Hall and A. Pakes (1991). "R\&D, Patents, and Market Value Revisited: Is There a Second (Technological Opportunity) Factor?," Economics of Innovation \& New Technology, 1 (3), pp.183-201.

Hall, B.H. (1988), "The Effect of Takeover Activity on Corporate Research and Development, Corporate Takeovers: Causes and consequences," A.J. Auerbach, ed, NBER Project Report series, University of Chicago Press, pp.69-96.

Hall, B.H. (1992), "Investment and Research and Development at the Firm Level: Does the Source of Financing Matter?," Working Paper, No.4096, NBER.

Hall, B.H. and J. van Reenen (2000), "How Effective are Fiscal Incentives for R\&D? A Review of the Evidence," Research Policy, 29 (4-5), pp.449-469.

Hao, K.Y. and A.B. Jaffe (1993), "Effect of Liquidity on Firms' R\&D Spending," Economics of Innovation \& New Technology, 2 (4), pp.275-82.

Hellmann, T. (1998a), “The Allocation of Control Rights in Venture Capital Contracts," RAND Journal of Economics, 29 (1), pp.57-76.

Hellmann, T. (1998b), “A Theory of Corporate Venture Investing,” mimeo., Stanford.

Hellmann, T. and M. Puri (1998), “The Interaction Between Product Market and Financing Strategy: The Role of Venture Capital," mimeo., Stanford. 
Henderson, R. (1993), "Underinvestment and Incompetence as Responses to Radical Innovation: Evidence from the Photolithographic Alignment Equipment Industry," RAND Journal of Economics, 24 (2), pp.248-270.

Himmelberg, C.P. and B. Petersen (1994), "R\&D and Internal Finance: A Panel Study of Small Firms in High-Tech Industries," Review of Economics \& Statistics, 76 (1), pp.38-51.

Holmstrom, B. (1989), "Agency Costs and Innovation," Journal of Economic Behavior and Organization, 12 (2), pp.305-327.

Hsu, D. (2000), "Do Venture Capitalists Affect Commercialization Strategies at Start-ups?" mimeo., MIT.

Hubbard, R.G. (1998), "Capital-Market Imperfections and Investment," Journal of Economic Literature, 36 (1), pp.192-225.

Kamien, M.I. and N.L. Schwartz (1982), Market Structure and Innovation, Cambridge University Press: Cambridge.

Klenow, P.J. (1996), "Industry Innovation: Where and Why," Carnegie-Rochester Conference Series on Public Policy, 44 (0), pp.125-50.

Klette, T. J., J. Moen and Z. Griliches (1999), "Do Subsidies to Commercial R\&D Reduce Market Failures? Microeconomic Evaluation Studies," Working Paper, NBER.

Kortum, S. and J. Lerner (1998), "Does Venture Capital Spur Innovation,” Working Paper, No.6846, NBER.

Kremer, M. (1998), "Patent Buyouts: A Mechanism for Encouraging Innovation," Quarterly Journal of Economics, 113 (4), pp.1137-67.

Launjouw, J. (1994), "Economic Consequences of a Changing Litigation Environment: The Case of Patents," Working Paper, No.4835, NBER.

Lerner, J. (1996), "The Government as Venture Capitalist: The Long-Run Impact of the SBIR Program," Working Paper, No. 5753, NBER.

Lerner, J. (1997), “An Empirical Analysis of a Technology Race," RAND Journal of Economics, 28 (3), pp.228-247.

Lerner, J. and R. Merges (1997), “The Control of Technology Alliances: An Empirical Analysis of the Biotechnology Industry," Working Paper, No.6014, NBER.

Levin, R., et.al. (1987), “Appropriating the Returns from Industrial Research and Development," Brookings Papers on Economic Activity, 3, pp.783-831.

Mansfield, E. (1995), Innovation, technology and the economy: Selected essays of Edwin Mansfield, Edward Elgar: London.

National Science Foundation, Division of Science Resources Studies, "Will Small Business Become the Nation's Leading Employer of Graduates with Bachelor's Degrees in Science 
and Engineering?" NSF 99-322, Project Officers: John Tsapogas and Lawrence M. Rausch; Mary Collins, Westat (Arlington, VA 1999).

Nelson, R.R. (1959), “The Simple Economics of Basic Scientific Research,” Journal of Political Economy, pp.297-306.

Rasmusen, E. (1988), “Entry for Buyout," Journal of Industrial Economics, 36 (3), pp.281-299.

Rausch, L. (1998), "Venture Capital Investment Trends in the United States and Europe," NSF 99-303.

Reinganum, J.F. (1989), "On the Timing of Innovation,” in R. Schmalansee and R. Willig (eds.), Handbook of Industrial Organization, Vol.1, Elsevier: Amsterdam, pp.849-908.

Romer, P. (1990), “Endogenous Technological Change," Journal of Political Economy, 98 (October), pp.S71-S102.

Rosenberg, N. (1974), "Science, Invention, and Economic Growth," Economic Journal, 84 (333), pp.90-108.

Scherer, F.M. (1965), "Firm Size, Market Structure, Opportunity, and the Output of Patented Inventions," American Economic Review, 55, pp.1097-1125.

Scherer, F.M. (1992), "Schumpeter and Plausible Capitalism," Journal of Economic Literature, 30, pp.1416-1433.

Schmookler, J. (1966), Invention and Economic Growth, Harvard University Press: Cambridge (MA).

Schumpeter, J.A. (1942), Capitalism, Socialism and Democracy, Harper: New York.

Stiglitz, J.E. and A. Weiss (1981), "Credit Rationing in Markets with Imperfect Information," American Economic Review, 71 (3), pp.393-410.

Stuart, T., H. Hong and R. Hybels (1999), "Interorganizational Endorsements and the Performance of Entrepreneurial Ventures," Administrative Science Quarterly, 44, pp.315349.

Teece, D.J. (1987), "Profiting from Technological Innovation: Implications for Integration, Collaboration, Licensing, and Public Policy," in D.J. Teece (ed.), The Competitive Challenge: Strategies for Industrial Innovation and Renewal, Ballinger: Cambridge (MA), pp.185-220.

Toole, A. (1999), “The Contribution of Public Science to Industrial Innovation: An Application to the Pharmaceutical Industry," Discussion Paper, No.98-6, Stanford Institute for Economic Policy Research.

Wallsten, S. (1998), "Rethinking the Small Business Innovation Research Program," in Investing in Innovation, L. Branscomb and J. Keller (eds.), MIT Press: Cambridge (MA). 
Wallsten, S. (2000), "The Effects of Government-Industry R\&D Programs on Private R\&D: The Case of the Small Business Innovation Research Program," Rand Journal of Economics, 31(1), pp.82-100. 